\title{
An East Siberian ice shelf during the Late Pleistocene glaciations: Numerical reconstructions
}

\author{
Florence Colleoni ${ }^{\mathrm{a},{ }^{*}, \text { Nina Kirchner }}{ }^{\mathrm{b}}$, Frank Niessen ${ }^{\mathrm{d}}$, Aurélien Quiquet ${ }^{\mathrm{a}}$, Johan Liakka ${ }^{\mathrm{c}}$ \\ a Centro Euro-Mediterraneo sui Cambiamenti Climatici, Bologna, Italy \\ b Department of Physical Geography, Bolin Centre for Climate Research, Stockholm University, Stockholm, Sweden \\ ${ }^{\mathrm{c}}$ Biodiversity and Climate Research Centre, Frankfurt am Main, Germany \\ d Alfred Wegener Institute, Helmholtz Centre for Polar and Marine Research, Bremerhaven, Germany
}

\section{A R T I C L E I N F O}

\section{Article history:}

Received 25 May 2015

Received in revised form

26 November 2015

Accepted 21 December 2015

Available online $\mathrm{xxx}$

\section{Keywords:}

Late Pleistocene glaciations

Arctic ocean

East Siberian ice shelf

Ice sheet model

Glacial climate

\begin{abstract}
A B S T R A C T
A recent data campaign in the East Siberian Sea has revealed evidence of grounded and floating ice dynamics in regions of up to $1000 \mathrm{~m}$ water depth, and which are attributed to glaciations older than the Last Glacial Maximum (21 kyrs BP). The main hypothesis based on this evidence is that a small ice cap developed over Beringia and expanded over the East Siberian continental margin during some of the Late Pleistocene glaciations. Other similar evidence of ice dynamics that have been previously collected on the shallow continental shelves of the Arctic Ocean have been attributed to the penultimate glaciation, i.e. Marine Isotopes Stage 6 ( $\approx 140$ kyrs BP). We use an ice sheet model, forced by two previously simulated MIS 6 glacial maximum climates, to carry out a series of sensitivity experiments testing the impact of dynamics and mass-balance related parameters on the geometry of the East Siberian ice cap and ice shelf. Results show that the ice cap developing over Beringia connects to the Eurasian ice sheet in all simulations and that its volume ranges between 6 and $14 \mathrm{~m} \mathrm{SLE}$, depending on the climate forcing. This ice cap generates an ice shelf of dimensions comparable with or larger than the present-day Ross ice shelf in West Antarctica. Although the ice shelf extent strongly depends on the ice flux through the grounding line, it is particularly sensitive to the choice of the calving and basal melting parameters. Finally, inhibiting a merging of the Beringia ice cap with the Eurasian ice sheet affects the expansion of the ice shelf only in the simulations where the ice cap fluxes are not large enough to compensate for the fluxes coming from the Eurasian ice sheet.
\end{abstract}

(c) 2016 Elsevier Ltd. All rights reserved.

\section{Introduction}

Recent Arctic data campaign results from Niessen et al. (2013) reveal evidence of grounded ice dynamics along the East Siberian continental margin (Fig. 1), in regions of up to $1200 \mathrm{~m}$ present-day water depth, and which are attributed to glaciations on Beringia older than the Last Glacial Maximum ( $\approx 21$ kyrs BP, LGM). Beringia is nowadays below present-day global mean sea level, forming the Beaufort, Chukchi, East Siberian and Laptev seas. During past glaciations, this area was emerged as a result of the sea level drop caused by the growth of the large Northern Hemisphere ice sheets (Fig. 1). In order to explain glacial lineations in sub-bottom sediments found on seamounts of the Mendeleev Ridge, namely the

\footnotetext{
* Corresponding author.

E-mail address: flocolleoni@gmail.com (F. Colleoni).
}

Arlis Plateau, Niessen et al. (2013) suggest that an ice cap developed over Beringia, large enough to allow for an ice shelf to develop in a semi-enclosed coastal configuration off the East Siberian continental margin during the Late Pleistocene glaciations (Fig. 1).

Over the last decade, various Arctic expeditions have revealed large-scale glacial erosion and glaciogenic bedforms on the seafloor down to approximately $1000 \mathrm{~m}$ below present sea level (e.g. Jakobsson, 1999; Polyak et al., 2001; Jakobsson et al., 2008), with likely different causes leading to their formation: Some of the evidence found on the Lomonosov Ridge has been attributed to large icebergs drifting with oceanic currents, or to a large floating ice shelf covering most of the Arctic Ocean (Jakobsson, 1999; Jakobsson et al., 2008). In contrast, evidence found along the Chukchi Borderland and along the Northern Alaskan margin is indicative of grounded ice dynamics of small ice caps (Polyak et al., 2001; Jakobsson et al., 2005, 2008; Engels et al., 2008). The mapped glacial erosional features are mostly dated to the penultimate 


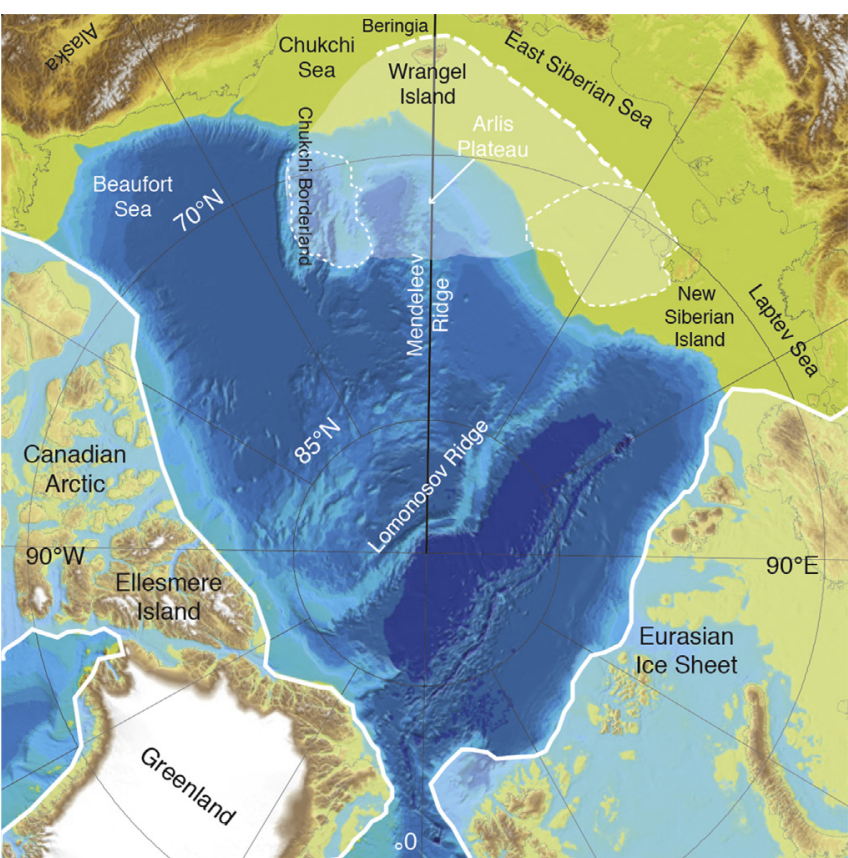

Fig. 1. MIS 6 glacial maximum ( $\approx 140$ kyrs BP) Arctic topography. Topography and bathymetry are from present-day ETOPO1 (Amante and Eakins, 2009) in which the sea level is set to $-120 \mathrm{~m}$ below mean global present-day sea level, therefore the Bering Strait and the East Siberian shelf are emerged. Extents from the MIS 6 Eurasian ice sheet from Svendsen et al. (2004) and from the ICE-5G Laurentide ice sheet from Peltier (2004) are drawn with a white thick continuous line. Speculative ice covered areas over East Siberian ice cap and ice shelf are after Niessen et al. (2013) including previous ice-cap reconstructions by Jakobsson et al. (2008) and Basilyan et al. (2008) for the Chukchi Borderland and the New Siberian Islands, respectively (indicated by a dashed white lines).

glacial cycle (Jakobsson et al., 2001, 2010, ₹192-135 kyrs BP). This implies that the largest ice shelves in the Arctic Ocean coexisted with the largest recorded extent of the Eurasian continental ice sheet, that occurred during Marine Isotope Stage 6 (MIS 6, Svendsen et al., 2004).

The MIS 6 glacial maximum ice-sheet topography is poorly constrained. Although the largest ice-sheet extent in records across Eurasia is attributed to the MIS 6 glacial maximum (Late Saalian, $\approx 140$ kyrs BP, Svendsen et al., 2004), the thickness of the MIS 6 ice sheet is poorly constrained. While Peyaud (2006) simulated a thick MIS 6 Eurasian ice sheet reaching a maximum elevation of $3500 \mathrm{~m}$ and a total ice volume of about 70 meters Sea Level Equivalent ( $\mathrm{m}$ SLE), Lambeck et al. (2006) simulated a thinner ice sheet (3000 m) leading to a total ice volume of about $60 \mathrm{~m}$ SLE during MIS6. In contrast, no geological evidence has been found for the MIS 6 glacial maximum Laurentide ice sheet; it reached its maximum Quaternary extent during the LGM, destroying the traces of the previous glaciations (Dyke et al., 2002). Consequently, the MIS 6 Laurentide ice sheet was smaller than or as large as during the LGM. Over East Siberia, Grosswald (1989); Hughes and Hughes (1994); Grosswald and Hughes (1999) proposed that during some of the Pleistocene glaciations, a large ice cap covered the Siberian Highs, the Siberian Lowlands and the Siberian continental shelf. Some geological evidence, indeed, indicates that the East Siberian Highs have been glaciated during the last glacial cycle (Stauch and Lehmkuhl, 2010) and also during MIS 6 glacial cycle (Nürnberg et al., 2011). On the continental margin of the Laptev Sea, the input of terrestrial organic matter has been used as an indicator of glacial erosion in the hinterland, which was significantly larger during MIS 6 compared to MIS 2 (Stein et al., 2001). However, Romanovskii and Hubberten (2001) state that the Laptev Sea has never been subject to glaciation but was characterised by thick permafrost formed on the exposed continental shelf during glacial times (Hinz et al., 1998). While it is widely accepted that the Laptev Sea continental shelf was not covered by an ice sheet during the LGM (Kleiber and Niessen, 1999; Svendsen et al., 2004; Schirrmeister et al., 2011) the extent of the continental ice sheet in the area during the MIS 6 glaciation is by far less understood (e.g. Möller et al., 2015).

In terms of ice shelf distribution, Mercer (1970) proposed that Antarctic-style ice shelves developed in the Arctic Ocean during the Pleistocene glaciations. Further, Hughes et al. (1977) suggested that during the LGM, a 1-km thick ice shelf potentially covered the entire Arctic Ocean and form a critical part of a huge ice sheet, including the Laurentide and Eurasian ice sheets, that behaved as one dynamic continental ice system. This model has been rejected for the LGM by most of the members of the Arctic scientific community due to lack of field evidence (Svendsen et al., 2004; Jakobsson et al., 2014). However, recent seafloor mapping revealed traces of ice dynamics on the Chukchi Borderland (Polyak et al., 2007; Engels et al., 2008; Dove et al., 2014), which are attributed to large ice shelves expanding from the Laurentide ice sheet over the Beaufort Sea during LGM. On the Lomonosov Ridge (Fig. 1), deep scour marks, representative of large drifting icebergs or a massive ice shelf, have been dated to MIS 6 (Jakobsson et al., 2001). More recently, Jakobsson et al. (2010) also attributed some of the evidence found on the Chukchi Borderland to MIS 6. The hypothesis of whether or not MIS 6 Arctic Ocean ice shelves were restricted to the shallow continental shelves or covered the entire ocean is still actively debated.

To test if MIS 6 climate conditions are favourable to the maintenance of a large ice shelf, Colleoni et al. (2010a) forced and atmospheric model by prescribing Jakobsson et al. (2010) Canadian ice shelf reconstruction and alternatively a fully ice-covered Arctic Ocean as suggested by Hughes et al. (1977). The simulated surface mass balance was positive, around $0.1-0.2 \mathrm{~m} / \mathrm{yr}$, for both ice shelf configurations, implying that a large ice shelf can develop and be maintained over the Arctic Ocean if the basal melting due to ocean heat fluxes and ice flux from the grounded ice sheets are also favourable to its maintenance.

In the present contribution, we investigate whether or not an ice cap could develop over Beringia and feed an ice shelf in the western Arctic Ocean off the East Siberian continental margin as suggested by Niessen et al. (2013) during the MIS 6 glacial maximum. In particular, Niessen et al. (2013) suggest that: (1) an Eastern Siberian ice cap have encompassed the New Siberian Islands, up to the Wrangle Island and was potentially connected to a small ice cap growing over the Chukchi Borderland (Fig. 1). This hypothesis is based on a connection of their own evidence of glacial landforms at the East Siberian continental margin to evidence found in the other regions mentioned above (Basilyan et al., 2008; Brigham-Grette, 2013; Jakobsson et al., 2008). If this ice cap was connected or not to the Eurasian ice sheet during MIS 6 or older glaciations as suggested by Grosswald and Hughes (1999) is still an open question, mostly because the western end of the East Siberian Sea and adjacent continental slope is only sparsely explored; (2) Niessen et al. (2013) suggested that this ice cap was large enough to feed a 1-km thick ice shelf, off the East Siberian continental margin, which grounded and formed an ice rise on the Arlis Plateau.

In order to test the Niessen et al. (2013) hypothese, we use a thermo-mechanical ice-sheet ice-shelf model, forced by the simulated climates of the MIS 6 glacial maximum ( $\approx 140$ kyrs BP) from Colleoni et al. (2014) to build an ice cap-ice shelf system over Beringia and the adjacent area of the western Arctic Ocean. We perform a series of idealised sensitivity simulations in which we vary the model parameters related to ice cap mass balance and ice 
shelf geometry. In addition to those experiments, we test if a connection between the Beringian ice cap and the Eurasian ice sheet is a necessary condition for the development of an ice shelf off the East Siberian continental margins. We also address selected climate feedbacks that could alter the behaviour of the ice cap-ice shelf system over Beringia and the adjacent area of the western Arctic Ocean, but that are only crudely represented in the ice sheet model.

The manuscript is structured as follows: in Section 2, we detail some aspects of the ice-sheet model and the design of the experiments; in Section 3, we analyse our numerical reconstructions of the Eastern Siberian ice cap and ice shelf. In Section 4, we embed our results in the ongoing discussion concerning East Siberian glaciations found in literature, and draw conclusions.

\section{Methods}

We force a 3D thermo-mechanical ice sheet model off-line with two climate states derived from two MIS 6 ice topographies, namely Topo1 and Topo2 (Fig. 2a and b), obtained from coupled Atmosphere-Ocean General Circulation Model (AOGCM) simulations. To investigate the growth of an ice shelf in the western Arctic Ocean, sensitivity experiments are carried out by varying the parameters related to the dynamics of the grounded and floating part of the ice sheet as well as the parameters related to the ice shelf mass balance.

\subsection{GRISLI ice-sheet model}

GRISLI is a 3D-thermo-mechanical ice sheet - ice stream - ice shelf model, able to simulate both grounded and floating ice Rommelaere and Ritz (1996); Ritz et al. (2001). The grounded part uses the Shallow Ice Approximation (Hutter, 1983; SIA) whereas ice shelves and ice streams are treated using the Shallow Shelf Approximation (MacAyeal, 1989; SSA). The ice shelf formulation in GRISLI allows for a more realistic calculation of the ice sheet growth, and particularly of the advance of ice onto the shallow continental shelves (e.g. Alvarez-Solas et al., 2011; Peyaud et al., 2007). Isostasy is calculated by means of the elastic-flexural lithosphere-asthenosphere model (Lemeur and Huybrechts, 1996) and geothermal heat fluxes are prescribed from Shapiro and Ritzwoller (2004). To account for anisotropy in GRISLI, two enhancements factors are prescribed, one for grounded ice, handled with the SIA ( $\left.E_{S I A}\right)$, and one for ice shelves, handled with the SSA $\left(E_{S S A}\right)$. Usually, $E_{S I A}$ is larger than 1, while $E_{S S A}$ is lower than 1 . Note that the position of the grounding line is determined according to a flotation criterion.

As input fields, GRISLI needs the mean annual and July air surface temperature as well as the mean annual total precipitation. During runtime, air surface temperature is corrected for elevation changes by means of two spatially uniform lapse rates, $\lambda_{m a}$ and $\lambda_{J J A}$, for mean annual and summer temperatures, respectively. Correction of the precipitation field is based on Charbit et al. (2002) who use an exponential function relating the corrected temperature with the saturation pressure of water vapour in the atmosphere by means of a corrective factor $\gamma$. Based on the Clapeyron relationship, this saturation ratio increases roughly exponentially with temperature. In addition, the precipitation fraction converted into snowfall follows Marsiat (1994). The ablation is calculated using the semiempirical Positive Degree Day method (PDD, Reeh, 1991) and part of the surface melt is able to refreeze. The surface mass balance is calculated as the difference between precipitations and ablation. Calving occurs at the ice shelf front at a prescribed thickness $H_{\text {calv }}$ if the upstream ice flux cannot maintain the ice shelf balance. Basal melting under the ice shelves takes a prescribed uniform value that can vary with depth. Unless otherwise stated, we use the default parameters listed in Table 1.

\subsection{Initial Northern Hemisphere ice topography}

As initial conditions, GRISLI needs the surface topography, including the ice sheets elevation, and the associated ice thickness. Following Colleoni et al. (2014), we use the two MIS 6 glacial maximum topographies, referred to as Topo1 and Topo2 (Fig. 2a and $b$ ), differing in ice elevation and extent over North America. Topo1 accounts for the LGM Laurentide topography (Peltier, 2004) while Topo 2 accounts for a smaller Laurentide ice sheet, taken from the last deglaciation transient ICE-5G simulation from Peltier

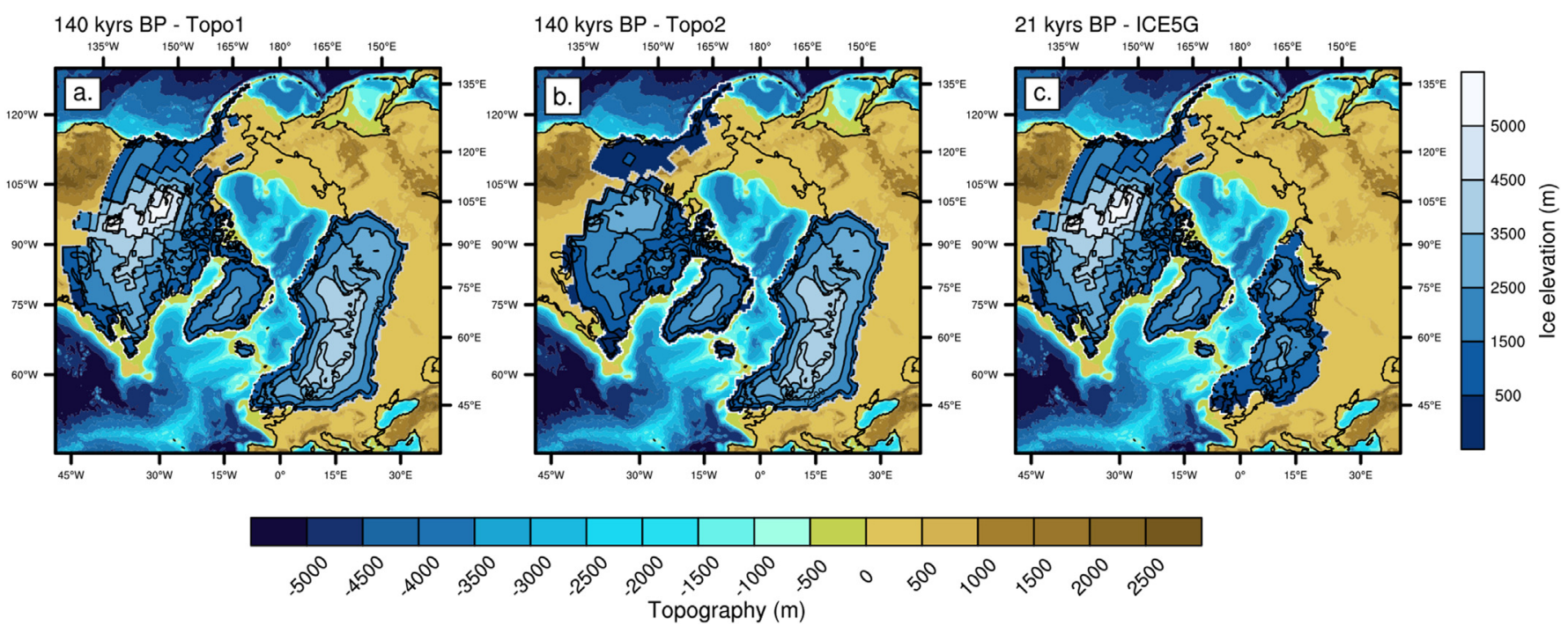

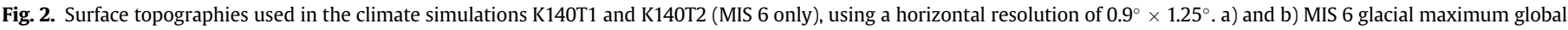

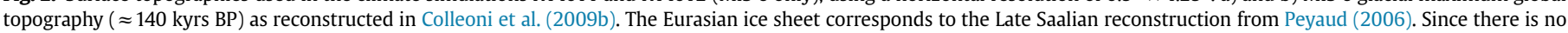

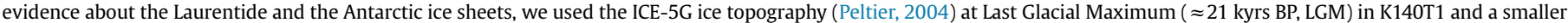

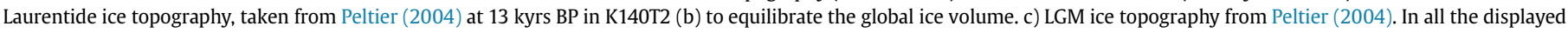
topographies, the Bering Strait is closed due to the glacial sea-level drop of about $120 \mathrm{~m}$. Note that the 0 level in the label bar corresponds to MIS 6 sea level. 
Table 1

Standard parameters used by GRISLI in the reference simulation SHELF001.

\begin{tabular}{|c|c|c|c|}
\hline Parameter & Default value & Unit & Description \\
\hline \multicolumn{4}{|c|}{ Enhancement factors } \\
\hline$E_{3}^{S I A}$ & 3 & dimensionless & SIA enhancement factor, Glen \\
\hline$E_{1}^{S I A}$ & 1 & dimensionless & SIA enhancement factor, linear \\
\hline$E_{3}^{S S A}$ & 0.37 & dimensionless & SSA enhancement factor, Glen \\
\hline$E_{1}^{S S A}$ & 0.37 & dimensionless & SSA enhancement factor, linear \\
\hline$T_{3}^{\text {trans }}$ & -6.5 & ${ }^{\circ} \mathrm{C}$ & Transition temperature of deformation, Glen \\
\hline$Q_{3}^{\text {cold }}$ & $7.820 \cdot 10^{4}$ & $\mathrm{~J} \cdot \mathrm{mol}^{-1}$ & Activation energy below transition, Glen \\
\hline$Q_{3}^{\text {warm }}$ & $9.545 \cdot 10^{4}$ & $\mathrm{~J} \cdot \mathrm{mol}^{-1}$ & Activation energy above transition, Glen \\
\hline$T_{1}^{\text {trans }}$ & -10 & ${ }^{\circ} \mathrm{C}$ & Transition temperature of deformation, linear \\
\hline$Q_{1}^{\text {cold }}$ & $4.0 \cdot 10^{4}$ & $\mathrm{~J} \cdot \mathrm{mol}^{-1}$ & Activation energy below transition, linear \\
\hline$Q_{1}^{\text {warm }}$ & $6.0 \cdot 10^{4}$ & $\mathrm{~J} \cdot \mathrm{mol}^{-1}$ & Activation energy above transition, linear \\
\hline \multicolumn{4}{|c|}{ Climate forcing } \\
\hline$\lambda_{m a} / \lambda_{I J A}$ & $5 / 4$ & ${ }^{\circ} \mathrm{C} / \mathrm{km}$ & Mean annual and summer lapse rates \\
\hline$\gamma$ & 5 & $\% / \mathrm{C}^{\circ}$ & Precipitation correction factor \\
\hline$p_{\text {solid }}$ & 2 & ${ }^{\circ} \mathrm{C}$ & Temperature threshold for rain/snow conversion \\
\hline \multicolumn{4}{|c|}{ PDD parameters } \\
\hline$C_{\text {ice }} / C_{\text {snow }}$ & $0.008 / 0.003$ & $\mathrm{~mm} / \mathrm{d} /{ }^{\circ} \mathrm{C}$ & Melting coefficients for ice and snow \\
\hline$\sigma$ & 5 & ${ }^{\circ} \mathrm{C}$ & Standard deviation of daily air temperature \\
\hline csi & 60 & $\%$ & Percentage of refreezing \\
\hline \multicolumn{4}{|c|}{ Ice streams parameters } \\
\hline sediment map & Laske and Masters (1997) & $\mathrm{m}$ & Map of sediment thickness \\
\hline$h_{s e d}^{*} / h_{w}^{*}$ & $150 / 250$ & $\mathrm{~m}$ & Critical sediment thickness and hydraulic head \\
\hline \multicolumn{2}{|l|}{ Ice shelf areas } & dimensionless & Basal dragging coefficient \\
\hline$H_{\text {calv }}$ & 150 & $\mathrm{~m}$ & Critical thickness of ice-shelf front \\
\hline$b_{\text {melt }}$ & 0.1 (depth $\leq 1500 \mathrm{~m}$ ) & $\mathrm{m} / \mathrm{yr}$ & Melting rate below ice shelves \\
\hline & 0.1 (depth $>1500 \mathrm{~m}$ ) & & \\
\hline \multicolumn{4}{|l|}{ Solid earth } \\
\hline$\tau_{r}$ & 3000 & yrs & Characteristic relaxation time \\
\hline GHF & Shapiro and Ritzwoller (2004) & $\mathrm{mW} / \mathrm{m}^{2}$ & Geothermal heat flux \\
\hline
\end{tabular}

(2004). A more detailed discussion about the MIS 6 glacial topographies adopted in this study can be found in Colleoni et al. (2014). Both Topo1 and Topo2 use the MIS 6 Eurasian ice topography from Peyaud (2006) (Fig. 2a and b). For comparison, we simulate the ice shelf expansion under Last Glacial Maximum climate conditions as simulated by Brady et al. (2013) and based on ICE-5G ice topography (Peltier, 2004, Fig. 2c). The LGM simulations are used in Section 4.1 to analyse the impact of climate forcing on the East Siberian glacial ice topography. Sea level is set to $-120 \mathrm{~m}$ below mean present-day one, which corresponds to the averaged sea level drop for both MIS 6 and MIS 2 glacial maxima as indicated by proxy-based sea level reconstructions (e.g. Waelbroeck et al., 2002; Rabineau et al., 2006).

\subsubsection{Climate forcing}

Mean annual and July surface air temperature and mean annual total precipitation are taken from Colleoni et al. (2014) who simulated two MIS 6 glacial maximum climates ( $\approx 140$ kyrs BP) using the fully coupled Atmosphere-Land-Ocean-Sea-Ice model CESM 1.0.5 (Gent et al., 2011). Note that in Colleoni et al. (2014), the CESM model is used as in its CCSM4 configuration, i.e. using CAM 4 atmospheric model version rather than the more recent version CAM 5 included in CESM 1.0.5. Those two MIS 6 simulations, referred to as K140T1 and K140T2, differ in the prescribed surface topographies described in the previous section, i.e. Topo1 and Topo2 (Fig. 2a and b). Both climate simulations K140T1 and K140T2 account for orbital parameters (Berger and Loutre, 1991), $\mathrm{CO}_{2}(192$ ppmv, Petit et al., 1999), $\mathrm{CH}_{4}$ and $\mathrm{N}_{2} \mathrm{O}$ (401 ppbv, 217 ppbv, respectively, Spahni et al., 2005) as for the MIS 6 glacial maximum. During the MIS 6 glacial maximum, Earth is at perihelion in early December (mid-January for LGM) and eccentricity (0.033) and obliquity $\left(23.42^{\circ}\right)$ are large compared to their LGM values $(0.019$ and $22.95^{\circ}$ ). This orbital configuration enhances seasonal contrasts and is therefore more favourable for glaciation. As a consequence, we expect the simulated MIS 6 glacial maximum winters to be mild and summers to be particularly cold compared with LGM climate. In addition, the low $\mathrm{CO}_{2}$ and $\mathrm{CH}_{4}$ concentrations, i.e. comparable to those of the LGM (185 ppmv and 350 ppbv, respectively), further help to maintain glacial conditions in high latitudes.

To force our ice-sheet experiments, we use air surface temperature at $2 \mathrm{~m}$ and the total precipitation averaged over the last 50 years of K140T1 and K140T2. In addition, for the sake of comparison, the LGM climate (NCAR21 hereafter) from Brady et al. (2013), carried out using the same AOGCM is also used to force GRISLI. Note that in NCAR21, the carbon-nitrogen bio-geochemistry is interactive and allows for the vegetation phenology to change and to impact on the surface albedo. In contrast, in the K140T1 and K140T2 simulations, the vegetation phenology was not allowed to change. Nevertheless, the comparison with Brady et al. (2013) LGM simulation is only indicative and introduced in Section 4.1 to support the discussion of the present work. In the present paper, we only briefly describe the MIS 6 Arctic temperature and precipitation for K140T1 and K140T2, which are the variables of interest in the framework of our ice sheet simulations (Section 3.1). For a more detailed description of the MIS 6 and LGM climates, the reader may refer to Colleoni et al. (2014) and Brady et al. (2013).

\subsubsection{Ice-sheet experiments}

The experiments are designed on a $40-\mathrm{km}$ regular rectangular grid from $\approx 37^{\circ} \mathrm{N}$ to the North Pole. The three initial ice topographies displayed in Fig. 2 are spun up for 200,000 years using the two MIS 6 climate forcing from Colleoni et al. (2014) while the LGM climate forcing comes from Brady et al. (2013). To start from ice-free conditions over East Siberia, high surface temperatures are imposed over the ice-free areas in Topo1 and Topo2. The spin-ups are then used as initial conditions for all the sensitivity 
Table 2

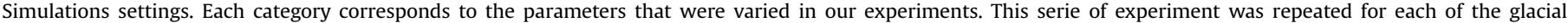

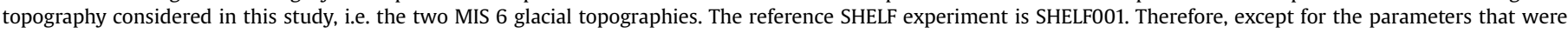
varied, all the other parameters are assumed to be identical with SHELF001. See Table 1 for more details on the parameters.

\begin{tabular}{|c|c|c|c|c|c|c|}
\hline Run ID & Enhancement factors (dimensionless) & Basal melting (m/yr) & $H_{\text {calv }}(\mathrm{m})$ & Lapse rate $\left({ }^{\circ} \mathrm{C} / \mathrm{km}\right)$ & $\operatorname{PDD} \sigma^{\circ} \mathrm{C}$ & Sediments \\
\hline \multicolumn{7}{|c|}{ SIA and SSA enhancement factors: } \\
\hline SHELF001 & $E^{S I A}=3 ; E_{3}^{S S A}=0.37$ & 0.1 & 150 & $5 / 4$ & 5 & no sedim. \\
\hline SHELF002 & $E^{S I A}=3 ; E^{S S A}=0.60$ & - & - & - & - & - \\
\hline SHELF003 & $E^{S I A}=5 ; E^{S S A}=0.80$ & - & - & - & - & - \\
\hline \multicolumn{7}{|c|}{ Basal hydrology: } \\
\hline SHELF004 & - & - & - & - & - & sediment map \\
\hline \multicolumn{7}{|c|}{ Calving and basal melting: } \\
\hline SHELF005 & - & - & 200 & - & - & - \\
\hline SHELF006 & - & - & 100 & - & - & - \\
\hline SHELF007 & - & $\begin{array}{l}\text { 0/0.2 } \\
\text { depth limit: }-1500 \mathrm{~m}\end{array}$ & - & - & - & - \\
\hline SHELF008 & - & $\begin{array}{l}0 / 0.2 \\
\text { depth limit: }-500 \mathrm{~m}\end{array}$ & - & - & - & - \\
\hline \multicolumn{7}{|c|}{ Surface mass balance: } \\
\hline SHELF009 & - & - & - & $8 / 6.5$ & - & - \\
\hline SHELF010 & - & - & - & - & 1 & - \\
\hline
\end{tabular}

experiments detailed in Table 2.

In total, for each MIS 6 topography, 10 experiments, SHELF001 to SHELF010, testing the impact of Glen's flow law enhancement factors for both SIA and SSA, basal melting under the shelves, calving and surface mass balance parameters, are carried out (Table 2). The simulations are run for 30,000 years, using the steady-state climate conditions described in the next section. SHELF001 serves as a reference simulation and the model parameters used for this control run are reported in Table 1. The set of experiments is repeated for both MIS 6 topographies and if not modified, the parameters are kept identical to SHELF001.

\section{Results}

\subsection{Climate forcing}

Mean annual air temperature (MAAT hereafter) in K140T1 amounts to about $-34^{\circ} \mathrm{C}$ over the western Eurasian Arctic and to about $-28^{\circ} \mathrm{C}$ over the Canadian Arctic and the East Siberian Arctic margins (Fig. 3a). MAAT reaches about $-40^{\circ} \mathrm{C}$ in the central part of the Eurasian ice Sheet and about $-35^{\circ} \mathrm{C}$ in central Greenland and over the northern part of the Laurentide ice sheet (Fig. 3a). Summer temperature are positive over Alaska, the emerged Bering Strait and the eastern part of Beringia as shown for July (Fig. 3d). The $0^{\circ} \mathrm{C}$ isotherm reaches the coastlines along the margins of Alaska and of the Bering Strait area. July temperature remains negative over the western part of Beringia and averages about $-10^{\circ} \mathrm{C}$ over this area. As a result of the ice sheets elevation along the Arctic Ocean margins and of the low temperature, precipitation decreases to rates lower than $0.2 \mathrm{~m} / \mathrm{yr}$ (Fig. $3 \mathrm{~g}$ ).

The smaller and lower Laurentide topography prescribed in K140T2 causes an increase in surface air temperature of about $4^{\circ} \mathrm{C}$ over the northern part of the Eurasian ice sheet and of about $6^{\circ} \mathrm{C}$ over the northern part of the Laurentide ice sheet compared to K140T1 (Fig. 3b). Furthermore, the simulated MAAT over Alaska and Eastern Siberia drops by ca. $6^{\circ} \mathrm{C}$ compared with K140T1. The July temperatures are similar over the western part of Beringia but are reduced by about $8^{\circ} \mathrm{C}$ in Alaska and East Siberia in K140T2 compared to K140T1 (Fig. 3e). Precipitation is approximately $30 \%$ higher over the western part of the Eurasian ice sheet and doubles along the western edge of the Laurentide compared with K140T1 (Fig. 3h). This is because the jet stream is shifted northward compared with K140T1 as a result of the lower North America orography prescribed in Topo2 (not shown, Colleoni et al., 2014). In addition, as a result of the lower prescribed ice elevation over the
Cascadian mountain range in K140T2, 40\% more precipitation reaches the Beaufort Sea compared to K140T1. The lower Laurentide elevation induces changes in the synoptic atmospheric circulation, which causes a decrease in precipitation of about $20 \%$ over Beringia in K140T2 compared with K140T1 (Fig. 3h).

\subsection{Simulated reference ice-sheet surface mass balance}

The surface mass balance (SMB) computed by GRISLI is positive over the entire Arctic Ocean in all three reference simulations using the SHELF001 parameter set for MIS 6 and for LGM (Fig. 4a to 4c). The spatial pattern of SMB results from the distribution of precipitation over the Arctic Ocean. The SMB reaches about $0.15 \mathrm{~m} / \mathrm{yr}$ on average in both MIS 6 simulations (Fig. $4 \mathrm{a}$ and b) and about $0.1 \mathrm{~m} / \mathrm{yr}$ in the LGM simulation (Fig. 4c). In the western Arctic Ocean and along the Canadian archipelago, the simulated MIS 6 SMB is the largest, up to $0.24 \mathrm{~m} / \mathrm{yr}$ and $0.3 \mathrm{~m} / \mathrm{yr}$, respectively when using K140T1 (Fig. 4a). The lowest SMB occurs along the margins of the Barents and Kara Seas (about $0.06 \mathrm{~m} / \mathrm{yr}$ ) and is negative in the Beaufort Sea because no precipitation reaches this area in K140T1 climate forcing and summer temperatures are positive (Fig. $3 \mathrm{c}$ and $3 \mathrm{~d})$. When using K140T2 instead, the maximum SMB value is shifted along the coasts of Alaska but is of the same order of magnitude than when using K140T1, i.e. up to $0.24 \mathrm{~m} / \mathrm{yr}$ (Fig. 4b). The maximum SMB is simulated in the Fram Strait as a consequence of the large precipitation rates from K140T2 climate forcing (Fig. 3e). In the LGM reference simulation, the SMB spatial pattern is similar to that of the MIS 6 simulation when using K140T1. The maximum SMB occurs in the area of the East Siberian Sea, about $0.16 \mathrm{~m} / \mathrm{yr}$ and along the Canadian margins, about $0.26 \mathrm{~m} / \mathrm{yr}$ (Fig. 4c). Note that in the Beaufort Sea, as a result of the lack of precipitation in the climate forcing and of positive summer temperatures over this area, the simulated SMB is negative (ablation occurs during summer).

When using K140T1, the simulated SMB is positive over the actual Laptev Sea region, close to the Eurasian ice sheet but is negative over the easternmost part of Beringia (Fig. 4a). When using $\mathrm{K} 140 \mathrm{~T} 2$, and as a result of the lower temperature simulated over East Siberia and Alaska compared with K140T1 (Fig. 4b), the SMB is positive over the entire emerged East Siberian continental shelf (Fig. $4 \mathrm{~b}$ ). These SMB patterns are constrained by the summer temperature as displayed in Fig. $3 b$ and $d$. As shown in the following sections, this parameter determines the geographical extent of the ice cap over this area. 

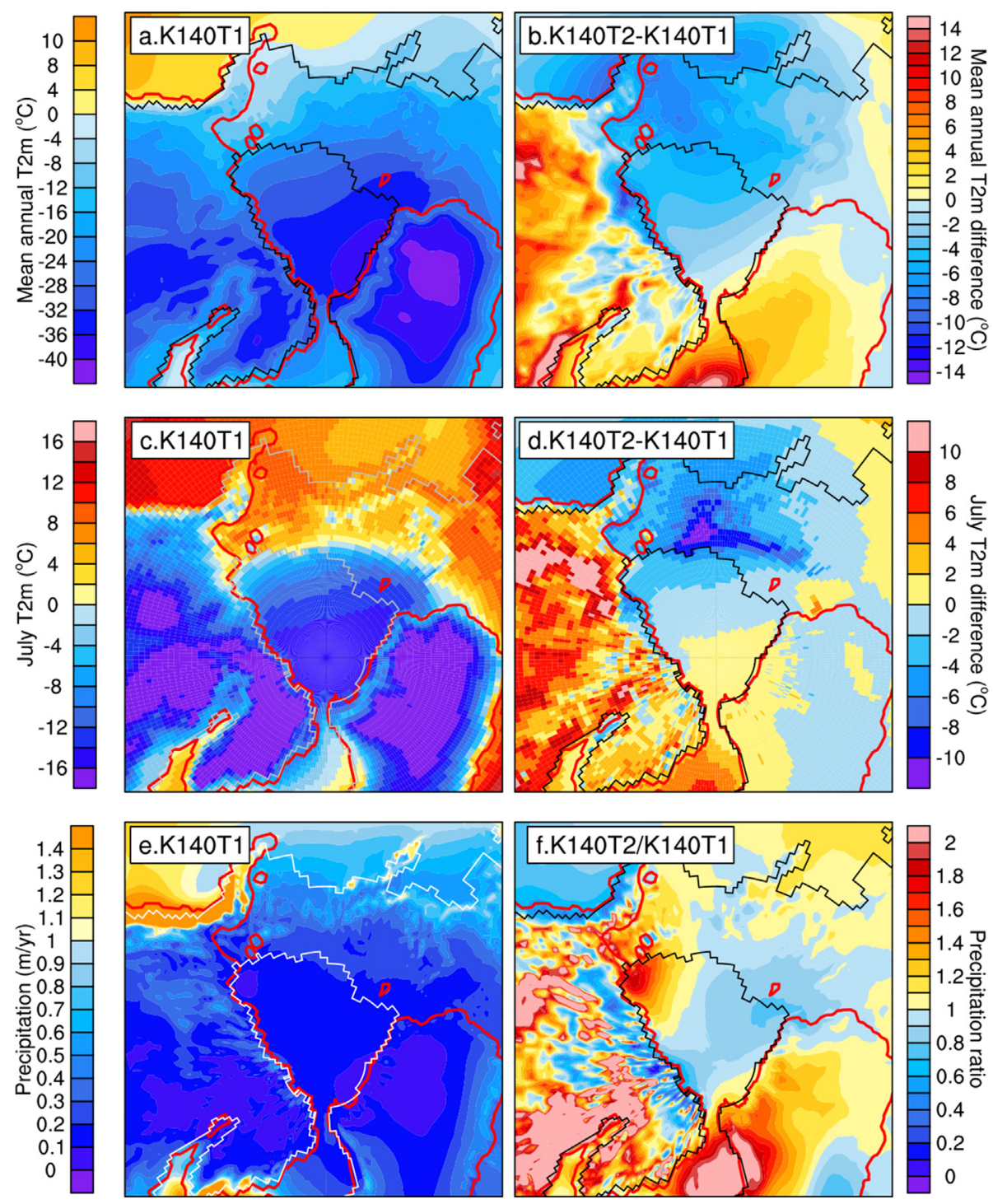

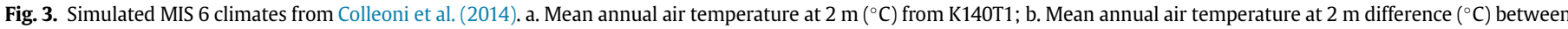

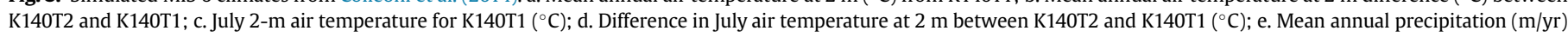
from K140T1; f. mean annual precipitation changes (ratio, dimensionless) between K140T2 and K140T1.

\subsection{Simulated reference ice topography}

In the following, the modelled ice shelf over the East Siberian Sea will be analysed quantitatively, while ice shelves developing in the Laptev Sea and elsewhere will only be described qualitatively. When using the K140T1 climate forcing (Fig. 4d), an ice cap develops over the East Siberian continental margin, connected with the Eurasian ice sheet. Two ice shelves also develop, off the actual Laptev Sea and off the actual East Siberian Sea (Fig. 4d). Small ice caps also develop over the Siberian mountain range and over the Kamchatka Peninsula. The ice volume accumulated in the ice cap represents $6.14 \mathrm{~m}$ SLE. For comparison, this is similar to the present-day Greenland ice volume (Bamber et al., 2013). After 30000 years of simulation, the ice cap volume reaches equilibrium (Fig. 6a, black thick line). The maximum grounded ice thickness is $2791 \mathrm{~m}$ and is located over the present Laptev Sea (Fig. 5a and Table 3). The ice shelf growing off the East Siberian Sea starts to expand after 4000 years of simulation, i.e. when the maximum ice thickness of the ice cap reaches about $800 \mathrm{~m}$ (Fig. 6a). The final area of this ice shelf is about $42 \times 10^{4} \mathrm{~km}^{2}$, which is comparable to the
Ross ice shelf in East Antarctica $\left(49 \times 10^{4} \mathrm{~km}^{2}\right)$ and the maximum ice thickness, located at the outlet of the grounded zone, averages $290 \mathrm{~m}$ (Fig. 6b).

When using K140T2 climate forcing, the ice cap spreads over the entire Beringia, and connects with the East Siberian mountain range - Kamchatka peninsula (Fig. 4e). This is in agreement with Nürnberg et al. (2011) who show that the flux of ice-rafted debris (IRD) during MIS 6 was two to three times larger than during the LGM in the Okhotsk Sea, suggesting that the glaciation during MIS 6 was more extensive over the Kamchatka Peninsula. As a result of lower mean summer temperature over Beringia, the total grounded ice volume growing over this region (excluding the Siberian mountain range and the Kamchatka Peninsula) is about $14.26 \mathrm{~m}$ SLE after 30000 years of simulation, which is twice as big as when using K140T1 climate forcing (Table 3 and Fig. 3b). Two main domes form over East Siberia, the first one located over the current Laptev Sea and the second one located over the emerged Bering Strait (Fig. 4e). Equilibrium is reached 5000 years later and the maximum ice thickness is about $3000 \mathrm{~m}$. As in the case of K140T1, this ice cap is connected to the large Eurasian ice sheet. This point is further 

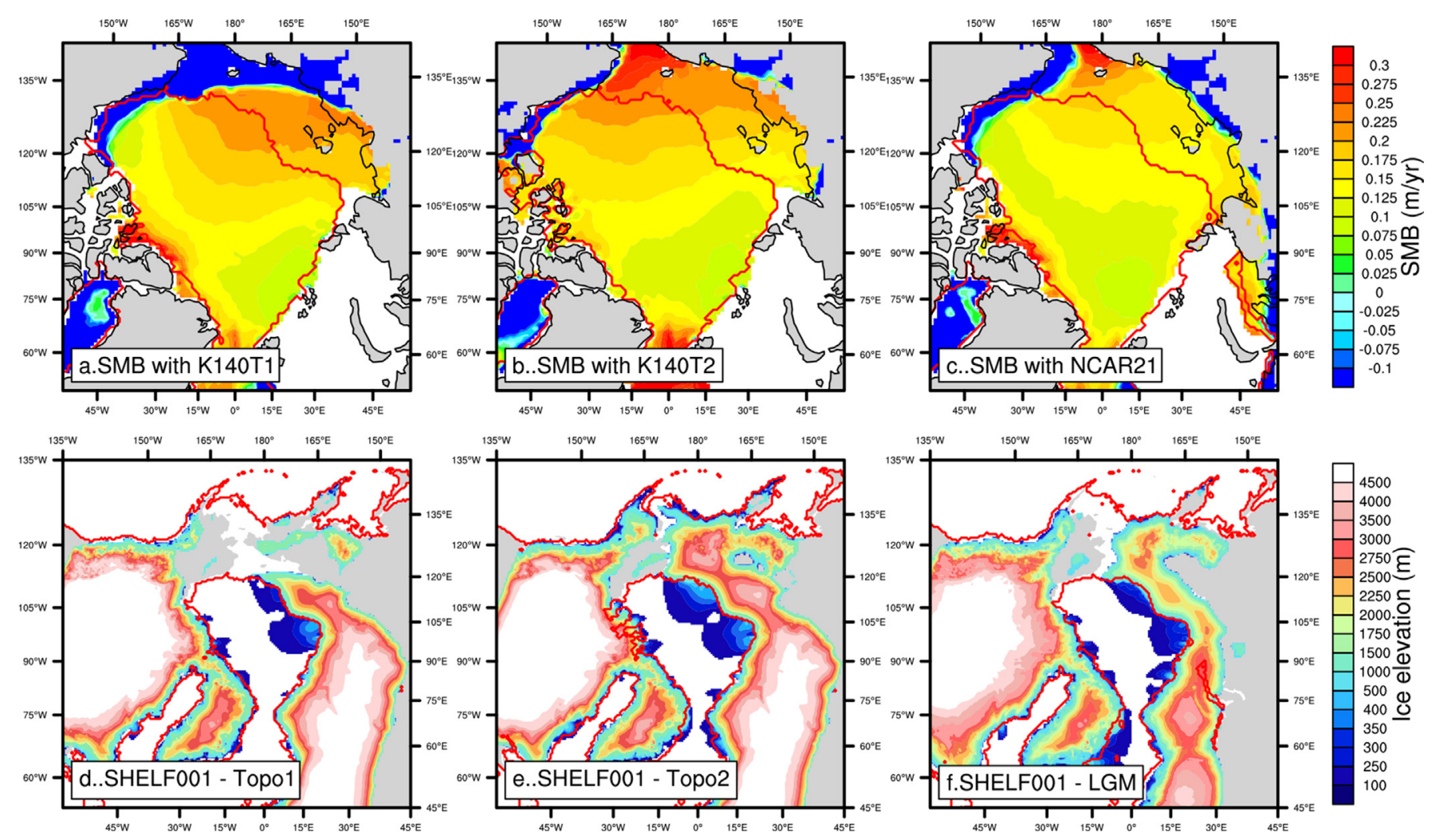

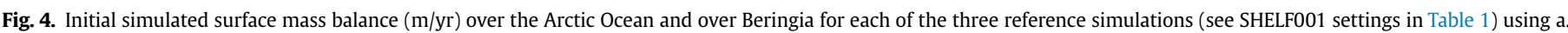

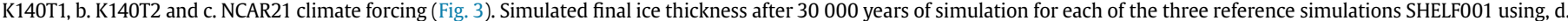

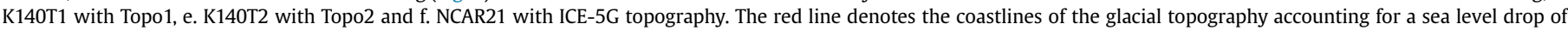
$120 \mathrm{~m}$ below mean global present-day level. (For interpretation of the references to colour in this figure legend, the reader is referred to the web version of this article.)

discussed in Section 4. As a result of the larger ice cap, the ice shelf growing in the area of the East Siberian Sea covers about $75 \times 10^{4} \mathrm{~km}^{2}$ (Fig. 7b), which is almost twice as large as in the case of K140T1 and the maximum ice thickness at the main outlets is in average $450 \mathrm{~m}$ (Table 3). It starts floating after 4000 years of simulation, i.e. when the grounded maximum ice thickness reaches circa $900 \mathrm{~m}$ (Fig. 7a).

There are no direct geological constraints on the extent of an ice shelf. By analogy, in Antarctica, most of the ice shelves develop over the shallow waters of the continental shelf and seldomly expand significantly beyond. In their work, Niessen et al. (2013) suggest that the extent of the ice shelf in the western Arctic Ocean would have covered the area between the Chukchi Borderland and the new Siberian Islands (Fig. 1) in order to explain glacial lineations formed by grounded ice in this area down to about $1000 \mathrm{~m}$ present water depth. A more geographically restricted reconstruction of the grounded part could be the key to constrain the ice shelf extent by limiting the ice flow through the grounding line. In the following we perform some sensitivity tests in which the ice-sheet model parameters related to ice flow and to ice shelf mass balance are varied.

\subsection{Impact of Glen's flow law enhancement factors and basal sediment layer}

Ma et al. (2010) used a full-Stokes anisotropic ice-sheet - iceshelves flow-line model to estimate the most suitable enhancement factors values to properly reproduce the observed ice flow for the past and current ice sheets (e.g. Durand et al., 2007). They deduce $E_{S I A}$ values ranging from 4.5 to 5.6 and $E_{S S A}$ values ranging from 0.58 to 0.71 . They conclude that to properly account for ice anisotropy, the ratio between $E_{S I A}$ and $E_{S S A}$ should range between 5 and 10. In our reference experiments SHELF001 (see Table 2), $E_{S I A}$ is set to 3 and $E_{S S A}$ is set to 0.37 . This gives a ratio $E_{S I A} / E_{S S A} \approx 8$. Two additional experiments, SHELF002 and SHELF003 test different ratio, i.e. $E_{S I A} / E_{S S A}=3 / 0.6=5$ and $E_{S I A} / E_{S S A}=5 / 0.8=6.25$.

In SHELF002, the enhancement factor for the SIA is identical to SHELF001, only the value of $E_{S S A}$ is increased. As a consequence, the ice volume and the maximum ice thickness are identical to that in the reference simulations SHELF001 using both K140T1 and K140T2 (Table 3). The ice shelf dimensions, on the contrary decreases compared with SHELF001, as a result of the enhanced ice flow. Because the ice velocities are higher, calving increases since the conditions to maintain the ice shelf are not fulfilled. As a consequence, the ice-shelf area reduces by about $60 \%$ when using K140T1 climate forcing and by $25 \%$ when using K140T2 (Table 3). In this latter case, the volume of the ice cap is large enough to feed the ice shelf and compensates for the enhanced ice flow.

In the case of SHELF003, both $E_{S I A}$ and $E_{S S A}$ values are increased. The ice cap elevation is consequently slightly lower (about $-150 \mathrm{~m}$ ), and the volume is smaller (by about $-0.5 \mathrm{~m} \mathrm{SLE}$ ) than in SHELF001 using both climate forcing (Table 3). As for SHELF002, the ice shelf area reduces by about $66 \%$ in the case of K140T1 and by about 30\% in the case of K140T2 (Fig. 5b and $g$ and Table 3).

The increased $E_{S I A}$ and $E_{S S A}$ values also impact on the timing of the ice shelf growth. While in SHELF001, the ice shelf starts spreading after 4000 years of simulations (using K140T1), in the case of SHELF002, the growth is delayed by about 4000 years, i.e. when the maximum grounded ice thickness reaches $\approx 1300 \mathrm{~m}$. This delay is further larger in SHELF003, i.e. about 7000 years when the maximum grounded ice thickness reaches $\approx 1600 \mathrm{~m}$ (Fig. 6a and b). 


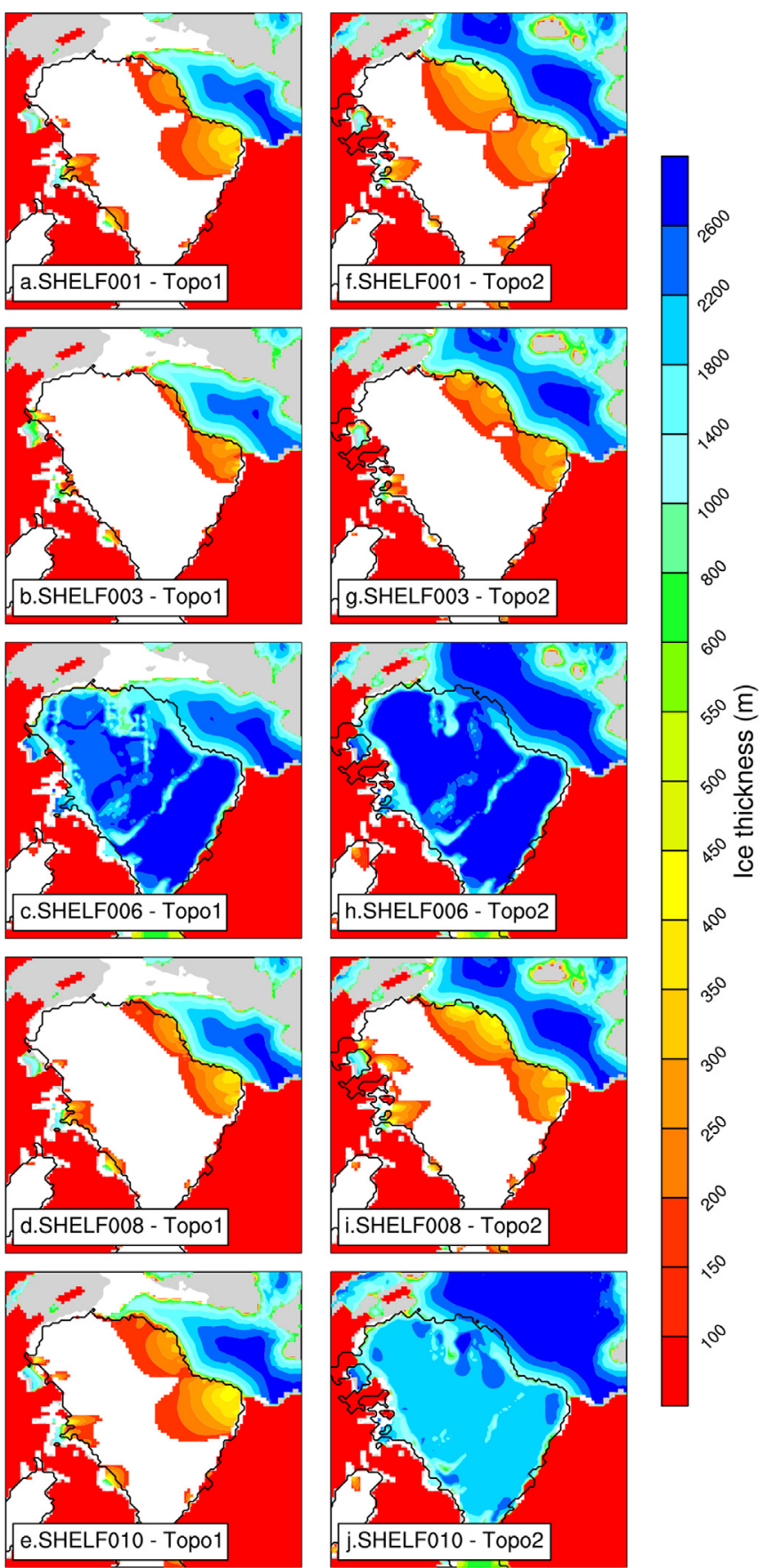

Fig. 5. Simulated ice thickness over Beringia and the East Siberian Sea for some selected experiments carried out and listed in Table 2: SHELF001 is the reference simulation; SHELF003 accounts for $E_{S I A} / E_{S S A}=5 / 0.8$; SHELF006 accounts for a low calving cut-off value of $100 \mathrm{~m}$; SHELF008 uses a basal melting of $0.2 \mathrm{~m} / \mathrm{yr}$ below 500 depth; SHELF010 tests a low standard deviation of the air temperature $\sigma=1^{\circ} \mathrm{C}$. Topo 1 and Topo 2 refers to the initial topography displayed in Fig. 2 and to the climate forcing K140T1 and K140T2. In the frames, the red shaded area correspond to the Laurentide and to the Eurasian ice sheet. (For interpretation of the references to colour in this figure legend, the reader is referred to the web version of this article.)

When using K140T2 climate forcing, the delay reduces by about 3000 years since the ice cap is generally large enough to partly compensate for the enhanced flow (Fig. 7a and b). Therefore, in SHELF003, which represents the lower bound of this group of experiments, the ice shelf starts spreading when the maximum grounded ice thickness reaches $\approx 1200 \mathrm{~m}$, i.e. $400 \mathrm{~m}$ less than in the case of K140T1.

Lastly, we include an experiment accounting for the impact of a sediment layer at the base of the ice sheet, namely SHELF004. The sediment distribution comes from Laske and Masters (1997) and, over Beringia, the thickness is of about $860 \mathrm{~m}$ (not shown). In GRISLI, the sediment layer thickness is used as a threshold, combined with basal melt water depth and with a topographic curvature criterion to determine the potential ice stream areas, which are treated with the SSA instead of SIA (Alvarez-Solas et al., 2011). In this experiment, almost no basal melting occurs at the base because the temperatures are too cold (not shown). Consequently, the absence of a layer of melt water at the base of the ice cap induces slow horizontal ice velocities, which inhibits the acceleration of the flow. Thus, the presence of some sediments at the base of the ice cap does not have any significant impact on its flow and most of the ice cap is treated with the SIA and only some marginal zones are treated with the SSA with increased horizontal velocities. This explains why the dimensions of the ice cap and of the ice shelf in SHELF004 are similar to those in SHELF001, using both climate forcing (Fig. 6a and $\mathrm{b}$ and $7 \mathrm{a}$ and $7 \mathrm{~b}$ ).

\subsection{Impact of calving and basal melting}

The two experiments testing the impact of the cut-off threshold for the ice thickness at the calving front, i.e. SHELF005 $\left(H_{\text {calv }}=200 \mathrm{~m}\right)$ and SHELF006 $\left(H_{\text {calv }}=100 \mathrm{~m}\right)$ give rise to endmembers among the results obtained from the whole set of experiments described in Table 2. While the calving threshold does not affect the grounded ice (Figs. 6c and 7c), it substantially affects the expansion of the ice shelf. In SHELF005, in the case of K140T1 climate forcing, the calving criterion is too strong and therefore, the ice shelf does not expand in the area of the East Siberian Sea (Fig. 6d). On the contrary, when using K140T2 climate forcing, the ice shelf expands, but only after 16,000 years of simulation (Fig. $7 d$ ). At this instance, the maximum grounded ice thickness reaches about $2300 \mathrm{~m}$ (Fig. 7), which is close to the final maximum ice thickness simulated using K140T1 for the same experiment (Fig. 6c). This indicates that in the case of K140T2 climate forcing, the ice fluxes through the grounding line are able to feed and sustain the ice shelf even if the calving threshold criterion is strong.

In SHELF006, setting the $H_{\text {calv }}$ to 100 m causes the ice shelves to spread quickly from the Eurasian margins and the Canadian Arctic margins under both climate forcing conditions. In slightly more than 2000 years, the Arctic is fully covered with a thin layer of ice. At the end of the simulation, most of the ice is still floating and reaches a thickness up to $3000 \mathrm{~m}$ (Fig. $5 \mathrm{c}$ and $\mathrm{h}$ ). The ice becomes grounded only along the Lomonosov Ridge and on the shallow continental shelves around the Arctic Ocean. In Figs. 6d and 7d, indeed, the ice shelf area for SHELF006 starts decreasing after 6000 years of simulations because most the ice floating points accounted for calculation in the area of the East Siberian Sea become grounded. The calving cut-off threshold also impacts on the timing of the ice shelf growth. Prescribing the cut-off to $100 \mathrm{~m}$ allows the ice shelf to spread faster and earlier than in the other experiments, although the ice cap is still not as thick as in the other simulations (Figs. 6d and 7d). Note that at the end of the simulation, the ice cap is thicker than in SHELF001 because of a small buttressing effect caused by the thickening of the large ice shelf that covers the entire Arctic Ocean (Figs. 6d and 7d).

Basal melting is the other parameter that directly affects the expansion of the ice shelf over the ocean in GRISLI. In the reference experiment, it was uniformly set to $0.1 \mathrm{~m} / \mathrm{yr}$, independently from depth (Table 1). The choice of this value is motivated by the fact that GRISLI simulates a positive surface mass balance in the East 

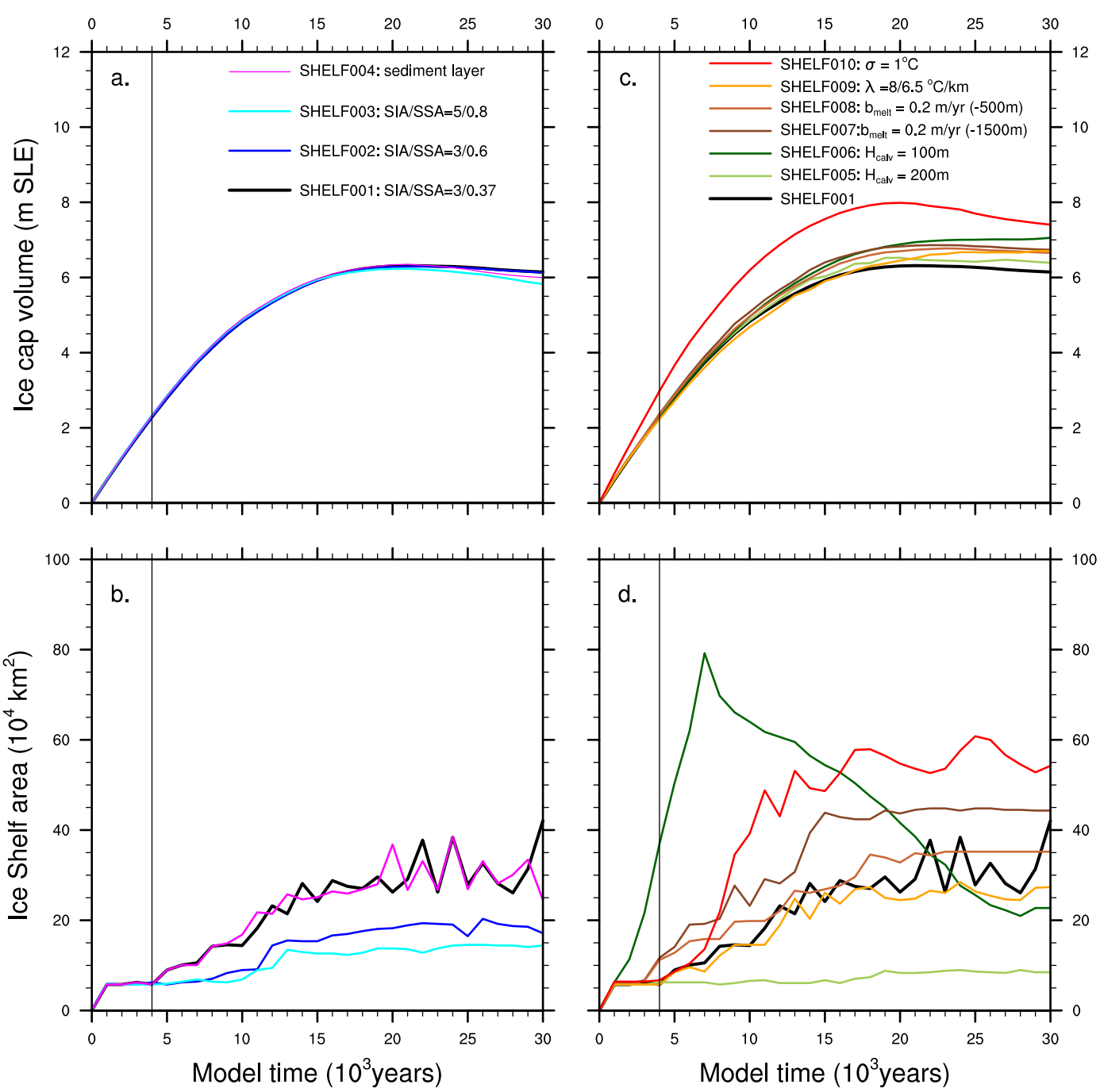

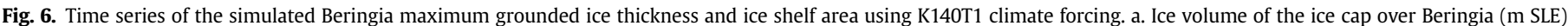

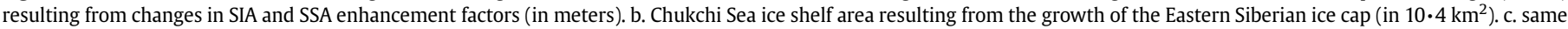

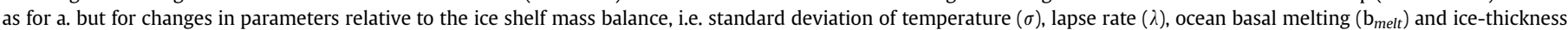

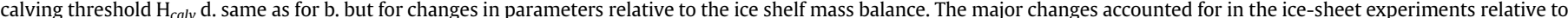

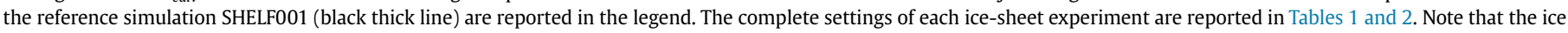
shelf expanding in the area of the Laptev Sea is not accounted for in those calculations since we only focus in the East Siberian Sea area.

Table 3

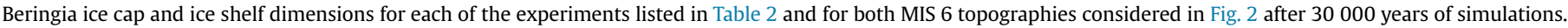

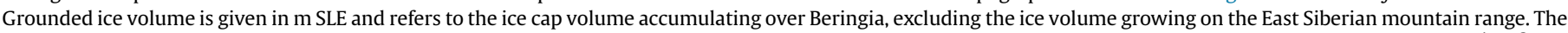

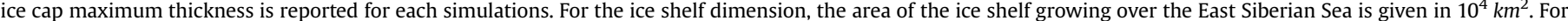

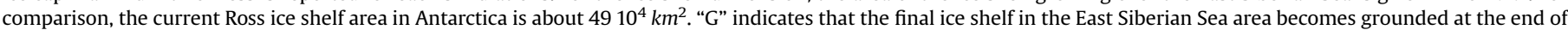

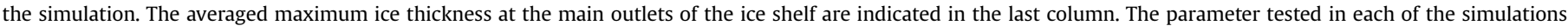

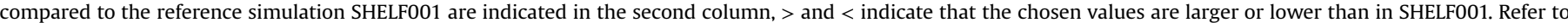
Table 2 for more details.

\begin{tabular}{|c|c|c|c|c|c|c|c|c|c|}
\hline \multirow[t]{2}{*}{ Run ID } & \multirow[t]{2}{*}{$\begin{array}{l}\text { Tested } \\
\text { Parameter }\end{array}$} & \multicolumn{2}{|c|}{$\begin{array}{l}\text { Grounded ice } \\
\text { Volume (m SLE) }\end{array}$} & \multicolumn{2}{|c|}{$\begin{array}{l}\text { Max. Thickness } \\
(\mathrm{m})\end{array}$} & \multicolumn{2}{|c|}{$\begin{array}{l}\text { Ice shelf area } \\
\left(10^{4} \mathrm{~km}^{2}\right)\end{array}$} & \multicolumn{2}{|c|}{$\begin{array}{l}\text { Max. Ice shelf } \\
\text { Thickness (m) }\end{array}$} \\
\hline & & Topo1 & Topo2 & Topo1 & Topo2 & Topo1 & Topo2 & Topo1 & Topo2 \\
\hline SHELF001 & Ref & 6.14 & 14.26 & 2791 & 3036 & 42.07 & 75.36 & $280-300$ & $440-460$ \\
\hline SHELF002 & $<\mathrm{SSA}$ & 6.13 & 13.59 & 2790 & 3037 & 17.11 & 56.47 & $250-270$ & $360-380$ \\
\hline SHELF003 & $<$ SIA/SSA & 5.82 & 13.05 & 2633 & 2917 & 14.39 & 53.27 & $220-240$ & $340-360$ \\
\hline SHELF004 & Sedim. map & 5.99 & 13.62 & 2715 & 3025 & 24.47 & 74.08 & $270-290$ & $400-420$ \\
\hline SHELF005 & $>H_{\text {calv }}$ & 6.38 & 13.12 & 2794 & 3036 & 8.47 & 26.07 & 260 & $380-400$ \\
\hline SHELF006 & $<H_{\text {calv }}$ & 7.05 & 15.74 & 3009 & 3388 & G & G & - & - \\
\hline SHELF007 & $<b_{\text {melt }}$ & 6.73 & 14.17 & 2793 & 3036 & 44.31 & 72.96 & $300-320$ & $400-460$ \\
\hline SHELF008 & $>b_{\text {melt }}$ & 6.65 & 13.95 & 2793 & 3034 & 35.19 & 61.11 & $300-320$ & $400-420$ \\
\hline SHELF009 & $>\lambda_{m a} / \lambda_{J J A}$ & 6.70 & 14.35 & 2828 & 3032 & 27.35 & 73.76 & 270 & $380-400$ \\
\hline SHELF010 & $<\sigma$ & 7.40 & 20.28 & 2897 & 4143 & 54.23 & G & $310-320$ & - \\
\hline Dust & 6.81 & 12.31 & 2857 & 3032 & 23.03 & 64.47 & 280 & $360-380$ & \\
\hline Connection & 5.27 & 12.21 & 2642 & 3000 & 23.99 & 73.60 & 280 & $380-400$ & \\
\hline
\end{tabular}



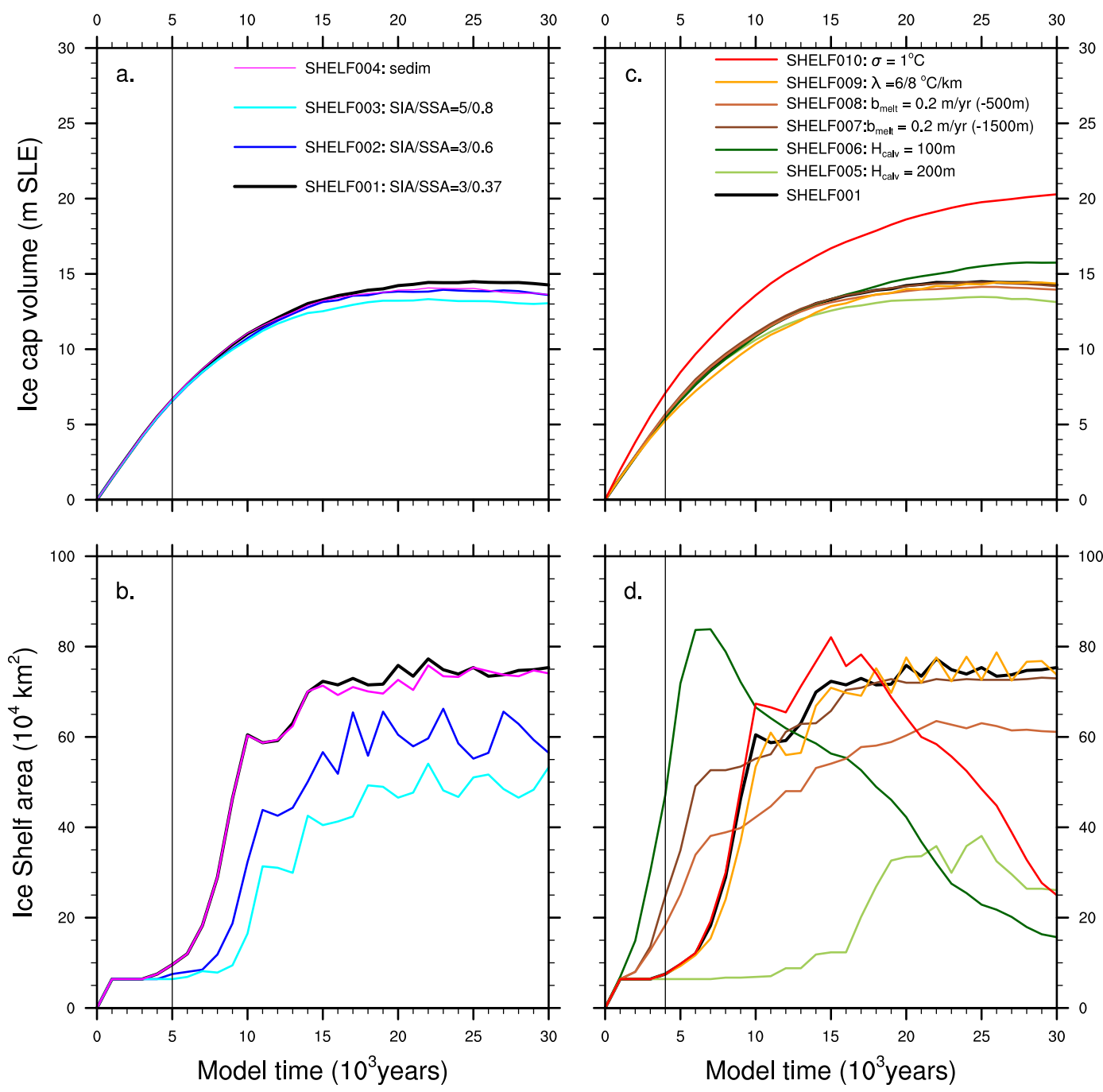

Fig. 7. Same as for Fig. 6 but using K140T2 climate forcing.

Siberian Sea of the order of 0.18-0.24 m/yr in both MIS 6 reference ice-sheet simulations (Fig. 4a and b). This implies that an ice shelf can expand in that area if the basal melting is set to a value lower than $0.18 \mathrm{~m} / \mathrm{yr}$. With the two climate forcing that we use in this study, the entire Arctic ocean is covered with a perennial $12 \mathrm{~m}$ thick sea-ice cover (Colleoni et al., 2014). This means that above the halocline, i.e. the uppermost $100-150 \mathrm{~m}$ of the ocean the simulated MIS 6 Arctic Ocean water temperatures are almost at the sea water freezing point $\left(\approx-1.7^{\circ} \mathrm{C}\right.$ ), implying that only very little or no basal melting occurs under the ice shelf at those depths. Therefore we impose no basal melting above $150 \mathrm{~m}$ depth and we prescribe a melt rate of $0.2 \mathrm{~m} / \mathrm{yr}$ below this depth (SHELF007). We further set this depth limit to $500 \mathrm{~m}$ in SHELF008. Note that in average, the basal melting is about $0.1 \mathrm{~m} / \mathrm{yr}$, as for SHELF001.

As expected, the ice shelf expands less in SHELF008 $\left(\approx 35 \times 10^{4} \mathrm{~km}^{2}\right.$ for K140T1 and $\approx 61 \times 10^{4} \mathrm{~km}^{2}$ for K140T2) than in SHELF001 for both climate forcing (Figs. $6 \mathrm{~d}$ and 7d). In the case of K140T1, the ice shelf does not expand beyond the continental shelf (Fig. 5d). When using K140T2, the ice fluxes at the grounded line partly compensate for the basal melting, which allows the ice shelf to expand beyond the depth limit (Fig. 5i). In SHELF007, the ice shelf does not expand farther than in SHELF001 because the ice shelf front thickness reaches the criteria for calving above the open ocean basin (Figs. 6d and 7d). The basal melting values influence the timing of the ice shelf expansion. Because we set the basal melting to $0 \mathrm{~m} / \mathrm{yr}$ in both SHELF007 and SHELF008 above the depth limit, the ice shelf starts expanding earlier than in SHELF001 (Figs. 6d and 7d).

\subsection{Impact of surface mass balance related parameters}

The last two experiments, SHELF009 and SHELF010, test the impact of the atmospheric lapse rate values $\lambda_{m a}$ and $\lambda_{J J A}\left(8^{\circ} \mathrm{C} / \mathrm{km}\right.$ and $6.5^{\circ} \mathrm{C} / \mathrm{km}$ ) and the impact of the standard deviation of daily surface air temperature $\sigma\left(1^{\circ} \mathrm{C}\right)$ on the SMB of the Beringia ice cap and ice shelf. Compared with SHELF001, increasing the lapse rate values induces a thicker ice cap in the case of K140T1 (Fig. 6c) while the ice cap does not reach a full equilibrium at the end of the simulation when using K140T2 climate forcing (Fig. 7c). However, those discrepancies with respect to SHELF001 are not large enough to substantially affect the ice flow through the grounding line and to significantly influence the timing of expansion and the dimension of the ice shelf off the East Siberian Sea (Figs. 6d and 7d).

The decrease in air surface temperature standard deviation in SHELF010 reduces the number of warm days occurring during the year and especially during summer. Therefore, the amount of ablation occurring during summer decreases, which leads to a larger ice cap extent in East Siberia and to a higher ice elevation. In 
response to the larger ice cap volume (Table 3), ice fluxes through the grounding line increase as well, causing the ice shelf to expand more than 28\% compared with SHELF001 (Fig. 5e). When using K140T2 climate forcing, the ice shelf growing in the area of the East Siberian Sea merges with the one growing off the actual Laptev Sea. It further expands during the simulation until reaching the Canadian shallow continental shelf and merges in turn with the ice shelves growing along the Laurentide ice sheet Arctic margins. This occurs after about 16000 years of simulation and induces a thickening of the Beringian ice cap through the buttressing effect (Fig. 5i). In Fig. 7c, there is a change of trend in the maximum ice thickness evolution towards 16000 model years. This is caused by the merging of all the Arctic ice shelves together and the thickening of the large unified ice shelf over the Arctic Ocean as in SHELF006. At the end of the simulation, the Arctic Ocean is fully covered with a $1800 \mathrm{~m}$-thick ice shelf, grounded only along the Lomonosov ridge and along the shallow continental shelves of the Arctic Ocean (Fig. 5j). As for SHELF006, because the ice shelf becomes grounded over the Arlis Plateau, the ice shelf area decreases through time in (Fig. 7d).

\subsection{East Siberian ice cap and ice shelf dimensions and geometry}

Compared with the ice cap dimensions suggested by Niessen et al. (2013) (Fig. 1), our closest numerical reconstructions are the ones obtained using K140T1 climate forcing (Fig. 5a to e). The reference SHELFO01 ice volume is $6.14 \mathrm{~m}$ SLE and except in SHELF006 and SHELF010 (thickening due to buttressing effect), the simulated ice cap volume in the other experiments is not significantly different from the reference value (Table 3). However, our simulated ice cap covers roughly twice the area suggested by Niessen et al. (2013) (Figs. 2 and 6a-d). When using K140T2, the ice cap covers Beringia entirely in all the simulations (Fig. $5 \mathrm{f}-\mathrm{i}$ ). In the reference simulation SHELF001, the total volume accumulated over the Beringia (excluding the ice accumulating over the Siberian mountain ranges) amounts to $14.26 \mathrm{~m}$ SLE and similarly to when using K140T1, in all the simulations, except SHELF006 and SHELF010, the ice volume does not substantially differ from the reference value (Table 3 ).

The area over which the ice cap grows in our simulations derives directly from the area where perennial snow accumulates in the climate simulations K140T1 and K140T2 (Fig. $3 \mathrm{~g}$ and i). In those two MIS 6 climate simulations, Beringia is emerged due to sea level drop and is considered as bare ground in the land surface model, i.e. no initial vegetation is prescribed over this newly emerged area. Therefore due to the low glacial Siberian temperatures, snow accumulates and becomes perennial. One consequence of this fact is that the simulated ice cap connects with the Eurasian ice sheet, which is contradictory with what Niessen et al. (2013) suggest. However this debate is still an open issue and we further discuss this aspect in the next Section.

In terms of ice shelf expansion, all the experiments successfully develop an ice shelf off the actual East Siberian Sea, except in the case of SHELF005 using K140T1. Most of the simulated ice shelves have an equilibrium area ranging from $42 \times 10^{4} \mathrm{~km}^{2}$ to $75.36 \times 10^{4} \mathrm{~km}^{2}$ (14 experiments out of 20 , Table 3 ), which is larger than the area covered presently by the Ross ice shelf $\left(\approx 49 \times 10^{4} \mathrm{~km}^{2}\right)$. The maximum floating ice thickness ranges between $270 \mathrm{~m}$ (with K140T1) to $460 \mathrm{~m}$ (with K140T2) close to the grounding line. Niessen et al. (2013) found mega-scale glacial lineations on the oceanic floor at about $900 \mathrm{~m}$ depth, yet, none of the 14 simulations performed here produces marine terminating ice streams thicker than $500 \mathrm{~m}$ at the grounding line (Fig. 5). However, in SHELF006 and in SHELF010, the whole Arctic Ocean is covered by an ice shelf, with ice thicknesses ranging from 1800 to $3000 \mathrm{~m}$. The only areas presenting grounded ice are located over the shallow continental shelves all around the Arctic Ocean and along the Lomonosov Ridge (not shown). Simulated grounding is in agreement with the geomorphological evidence dated to MIS 6 found by Polyak et al. (2001); Jakobsson et al. (2001, 2005, 2008, 2010).

\subsection{Dust induced snow-albedo feedback and connection with the Eurasian ice sheet}

Krinner et al. (2006) and Colleoni et al. (2009b) show the importance of the dust-albedo feedback on the perennial snow cover during the last two glaciations. In particular, Krinner et al. (2006) shows that during the LGM, the dust deposition on snow enables the melting of the perennial snow cover along the southern margin of the Eurasian ice sheet. This process could explain the absence of an ice cap in East Siberia during LGM. The simulated MIS 6 climate forcing from Colleoni et al. (2014) does not account for this feedback. Further, in all our simulations, the ice cap growing over Beringia is connected directly to the huge MIS 6 Eurasian ice sheet. In their interpretation, Niessen et al. (2013) do not connect the ice cap to the Eurasian ice sheet, while Grosswald and Hughes (1999) do connect it.

Both the dust-induced snow-albedo feedback and the connectivity with the Eurasian ice sheet influence the geometry of the ice cap and therefore the expansion of the ice shelf off the East Siberian Sea. To investigate this further, we performed two additional sets of simulations testing the impact of dust-albedo feedback (Dust) and the connection between the Beringia ice cap and the Eurasian ice sheet (Connection). These simulations have the same settings as the reference SHELF001 experiments and repeated for both sets of climate forcing (Table 1). The final ice topography for all these simulations is displayed in Fig. 8 and the ice volume and the ice shelf area are reported in Table 3.

\subsubsection{Impact of dust-snow-albedo feedback}

The MIS 6 climate forcing used here employs pre-industrial dust values. To better estimate the impact of changes in dust deposition, we superimpose the MIS6 climate anomalies resulting from the deposition of dust on snow simulated by Colleoni et al. (2009a) onto the climate forcing K140T1 and K140T2. The atmospheric model used in Colleoni et al. (2009a) accounts for the radiative feedbacks due to the darkening of the snow and the penetration of light in the snow pack based on the method in Krinner et al. (2006). The resulting mean annual anomaly over East Siberia is roughly $1^{\circ} \mathrm{C}$ (Fig. $8 \mathrm{~g}$ ), however, during the summer months, it rises to $2.5^{\circ} \mathrm{C}$ (not shown).

In the case of K140T1, the ice cap reaches nearly identical dimensions as in SHELF001 (Fig. 8a and c), i.e. $6.81 \mathrm{~m}$ SLE against $6.14 \mathrm{~m}$ SLE (Table 3). As a result of the slight temperature warming over the Arctic, the mass balance of the ice shelf off the East Siberian Sea is reduced, which limits its area to about $23 \times 10^{4} \mathrm{~km}^{2}$ instead of $42 \times 10^{4} \mathrm{~km}^{2}$ in SHELF001. When using K140T2, the sensitivity to the dust-induced temperature warming is larger than with K140T1, therefore the ice cap exhibits a larger decrease in ice volume, i.e. about $-1.95 \mathrm{~m}$ SLE (Table 3), although its extent remains similar to SHELF001 (Fig. 8b and d). The decrease in ice volume causes a slow down of the ice flow through the grounding line, which in turn reduces the ice shelf area (from about $75 \times 10^{4} \mathrm{~km}^{2}$ in SHELF001 to $64 \times 10^{4} \mathrm{~km}^{2}$ ). From these experiments, we conclude that the dust-albedo feedback has a moderate impact on the grounded ice, but has a larger impact on the ice shelf expansion since the climate is on average slightly warmer over the Arctic and the ice flux from the ice cap decreases. However, proper coupled climate-ice sheet simulations accounting for a more realistic dust transportation and deposition on snow for the MIS 6 


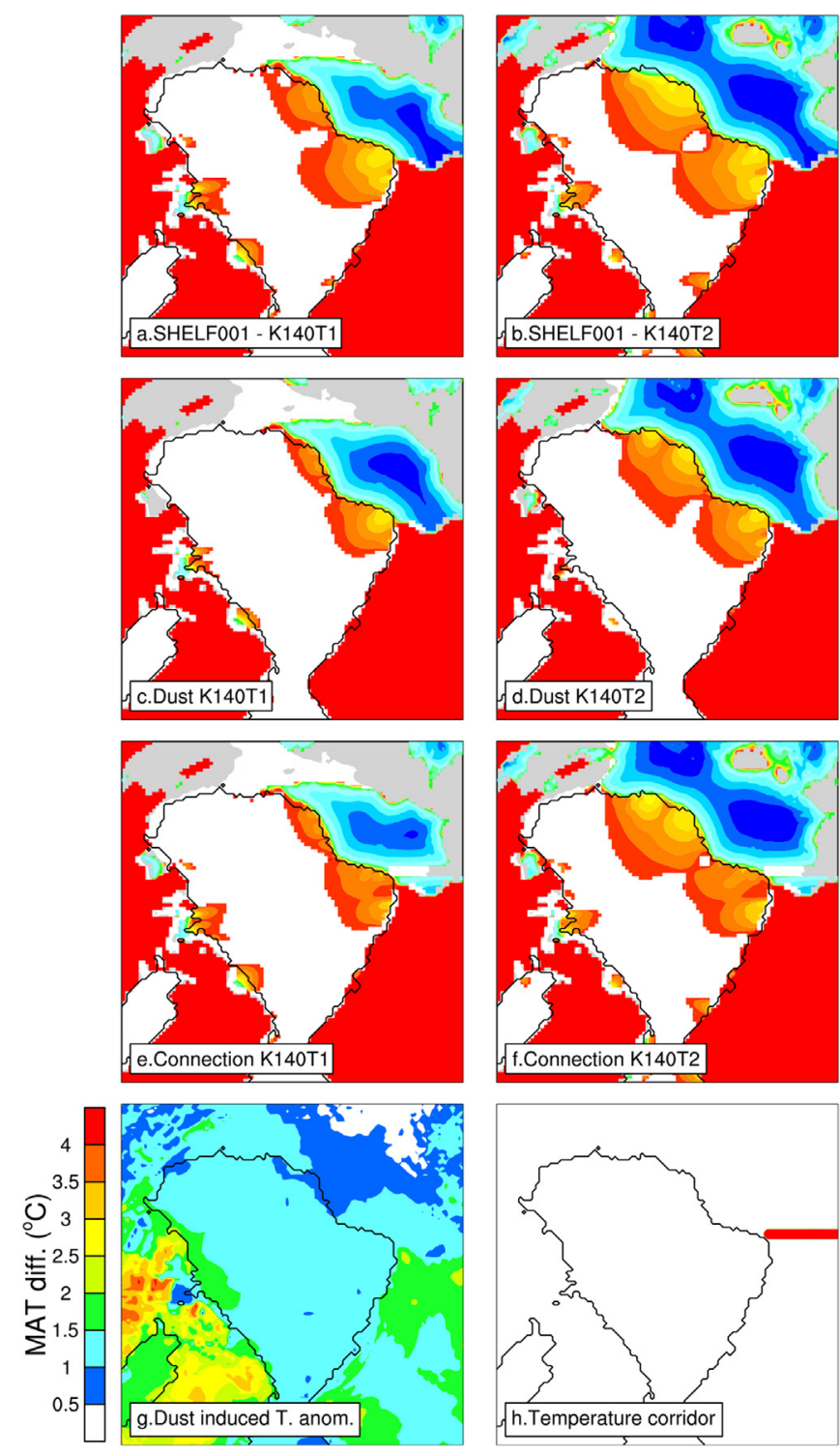

Fig. 8. Simulated final ice thickness over Beringia and the East Siberian Sea after 30000 years of integration for the reference simulations SHELF001 carried out using: a. K140T1 climate forcing; b. K140T2; Dust albedo feedback: the experiments are repeated to test the impact of the dust deposition on snow through the albedo feedback on local temperatures. In frames c. and d. K140T1 and K140T2 are perturbed using the monthly temperature anomaly (g.) simulated by Colleoni et al. (2009b) between MIS 6 glacial maximum accounting for the dust albedo feedback and a standard MIS 6 simulations without this effect (note that Colleoni et al., 2009b, used a stand-alone atmospheric model). Connection between the ice cap and the Eurasian ice sheet: the SHELF001 simulations are repeated again but we explicitly inhibit the connection between the Eurasian ice sheet and the ice cap over Beringia (frames e. and f.). The connection is inhibited by setting the temperature to $40^{\circ} \mathrm{C}$ in a small longitudinal band as displayed in frame $h$.

should be performed to fully investigate the impact on the growth of the ice cap and ice shelf over Beringia.

\subsubsection{Connection between the East Siberian ice cap and the \\ Eurasian ice sheet}

The results from our sensitivity experiments presented in Fig. 6 and Table 3 suggest that if the ice cap would have been restricted to the area suggested by Niessen et al. (2013, Fig. 1), its total ice volume could have been less than $6.14 \mathrm{~m}$ SLE, perhaps even less than $4 \mathrm{~m}$ SLE. In fact, the extent proposed by Niessen et al. (2013) is at least two times smaller than in our simulations (Fig. 1). On the contrary, if considering a connected system, following Grosswald and Hughes (1999), the ice cap could have covered the entire Beringia, which is what we predict in our simulations under K140T2 climate conditions. In that case, the ice volume of such a large ice cap reaches roughly $14 \mathrm{~m}$ SLE. For comparison, this volume amounts to twice the present-day volume of the Greenland ice sheet (Bamber et al., 2013).

To test whether or not the physical connection between the small ice cap and the MIS 6 Eurasian ice sheet influences the growth of the ice shelf over the ocean, we performed two simulations by explicitly inhibiting this connection: a narrow corridor characterised by an air surface temperature of $+40^{\circ} \mathrm{C}$ was prescribed between the Eurasian ice sheet and the ice cap (Fig. 8h). The final ice cap extent does not differ from SHELF001 (Fig. 8e and f), however, the ice volume is lower by about $1 \mathrm{~m}$ SLE using K140T1 and lower by about $2 \mathrm{~m}$ SLE using K140T2 (Table 3). In terms of ice shelf extent, the split between the ice cap and the Eurasian ice sheet induces a decline in the ice shelf area of about $57 \%$ compared with SHELF001 when using K140T1, while it remains almost similar when using K140T2 (Fig. 8e and f). This is because in the case of K140T2, the ice cap over Beringia is connected to the East Siberian mountain range ice cap and the ice flow feeding the ice shelf in the area of the East Siberian Sea comes mostly from the easternmost ice dome (Fig. 8f). Therefore, even if the ice cap gets disconnected from the Eurasian ice sheet, it is still able to sustain the ice shelf growth. On the contrary, in the case of K140T1, the ice cap over Beringia is not connected to the mountain range and the ice flow feeding the ice shelf comes from the dome developing over the actual Laptev Sea (Fig. 8e). As a consequence, when the ice cap is disconnected from the Eurasian ice sheet, the ice flow feeding the ice shelf weakens.

Inhibiting the connection between the ice cap and the Eurasian ice sheet does not prevent the ice shelf over the East Siberian Sea from growing. Inhibiting this connection only impacts the timing of the ice shelf development: in the case of K140T1, it takes a longer time to reach an area comparable to that in SHELF001; in the case of K140T2, the absence of connection does not have any significant impact on the growth of the shelf since the ice cap is autonomous and supported by the ice accumulating over the Siberian mountain range. Based on our simulations, we conclude that both a connected or a disconnected ice cap are viable scenarios allowing for an ice shelf to expand in the western Arctic Ocean.

\section{Discussion}

Using two previously simulated MIS 6 glacial maximum climate forcing (set at 140 kyrs BP) differing in the topography of the Laurentide Ice Sheet, we forced an ice-sheet model to investigate if an ice cap and its associated ice shelf could grow over Beringia and the western Arctic Ocean under simulated MIS 6 climate conditions, and to determine a possible range of geometries for the ice cap and ice shelf. From our numerical reconstructions, several questions arise: (1) We used two Late Saalian glacial maximum climate forcing generated by means of the CESM coupled climate model. Charbit et al. (2007) show that simulated climate forcing are model dependent and their use has a large impact on the simulated ice sheets geometry. (2) Ice shelf expansion is sensitive to the choice of basal melt rate. Basal melting was prescribed with a spatially and temporally uniform value, which is a highly simplified representation as in reality, circulation processes will imply spatiotemporally variables melt rates. (3) Rather than conducting more realistic transient experiments, we run equilibrium simulations of 30000 years with steady-state glacial climate forcing. This might impact on the final dimensions of the ice cap and on the extent of 
the ice shelf growing in western Arctic Ocean. In the following, we discuss all those points and their potential impact on our results.

\subsection{Sensitivity to climate forcing: comparison with Last Glacial Maximum}

To our knowledge, the Late Saalian maximum AOGCM climate simulations performed by Colleoni et al. (2014) are the only ones that exist for this specific period. This makes it impossible to investigate how sensitive the modelled ice cap-ice shelf system is to changes in climate forcing. How pronounced this sensitivity can be has been exemplified by Charbit et al. (2007) for LGM ice configurations. Since no alternative Late Saalian climate forcing is available, we use LGM climate forcing from two different AOGCMs to force our ice-sheet model, CESM 1.0.5 from Brady et al. (2013, hereafter referred to as NCAR21) and IPSL from Kageyama et al. (2013, hereafter referred to as IPSL21). The aim of those experiments is to examine the impact of an AOGCM on the numerical reconstructions over East Siberia. The settings of the ice-sheet experiments follow those of SHELF001 (Tables 2 and 1).

Compared with IPSL21, NCAR2 1 is about $8^{\circ} \mathrm{C}$ colder over East Siberia, which is associated with a negative anomaly in planetary waves over this area (Fig. 9c and d). This is because in NCAR21, a perennial snow cover develops over this area, while in IPSL21, this area remains ice free during summer (not shown). The discrepancy in the snow cover distribution probably results from the different treatment of vegetation in both models. In NCAR21, only the phenology is able to dynamically evolve during runtime, which allow for albedo changes, but not for changes in the vegetation distribution. In addition, newly emerged land areas, such as Beringia, are prescribed as "bare soil" in NCAR21. In IPSL21, on the contrary, changes in vegetation are fully dynamic. As a result, there is more vegetation over East Siberia (tundra type) in IPSL21 than in NCAR21, which prevents a perennial snow cover from accumulating.

In NCAR21, mean annual surface mass balance over the Arctic Ocean amounts to approximately $0.12 \mathrm{~m} / \mathrm{yr}$, slightly lower however than in K140T1 and K140T2 (Fig. 4c). Using this climate forcing, an
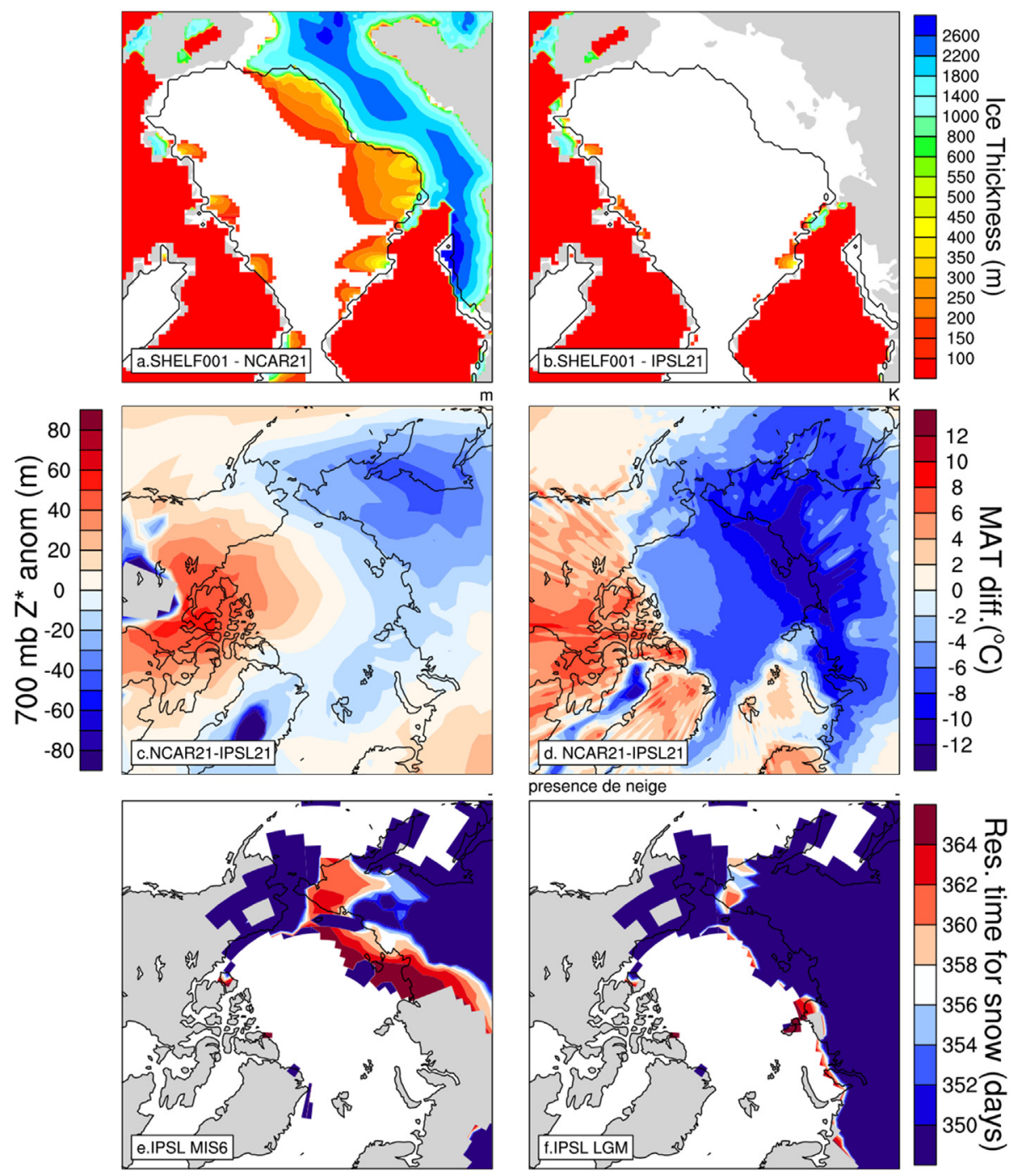

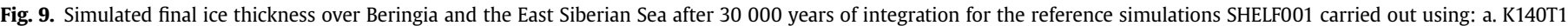

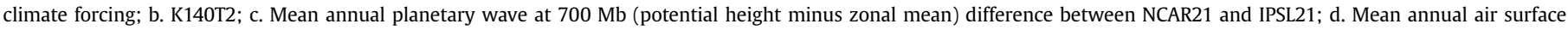

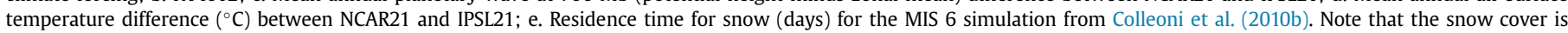

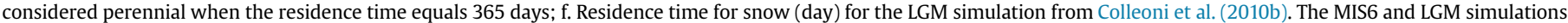

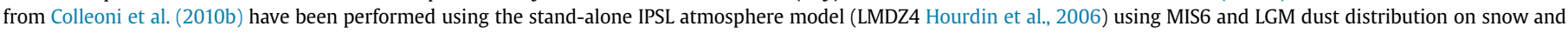
associated vegetation cover. 
ice cap and two ice shelves develop in East Siberia, of comparable dimensions than when using K140T1 and K140T2 climate forcing (Fig. 9a). In contrast, no ice cap develops over East Siberia when we force the ice-sheet model with ISPL21 (Fig. 9b). Since there is no geological evidence supporting the growth of an ice cap over Beringia during the LGM, we regard the IPSL climate forcing to imply the better match, while NCAR21 presents a cold bias over this area.

Is the MIS 6 perennial snow cover over East Siberia inherited from a cold bias of CESM or is it a robust feature of this glaciation? We compare two simulations from Colleoni (2009), one of LGM and one set at MIS 6 glacial maximum. Both simulations were carried out with the atmosphere model of IPSL (LMDZ4, Hourdin et al., 2006) in which vegetation distribution and sea surface temperatures were prescribed to LGM. While there is no perennial snow in the LGM simulation, consistent with IPSL21 coupled simulation, some perennial snow forms over Beringia in the MIS 6 simulation (Fig. 9e and $\mathrm{f}$ ). The presence of a perennial snow cover in both CESM and IPSL atmosphere model shows that MIS 6 could be a good candidate for a glaciation over Beringia. However, to properly investigate this issue, the MIS 6 glacial maximum climate should be simulated by other existing AOGCMs.

\subsection{Basal melting}

In our simulations, basal melting under the ice shelves was set to two values depending on depth but uniform in space and time. Instead we could have use few published basal melting parametrisations, such as Holland et al. (2008); Martin et al. (2011) to calculate a proper spatial distribution of basal melting. Those parametrisations rely on the state of vertical ocean temperature, salinity and horizontal velocities. If we use the simulated ocean vertical temperature from K140T1 and K140T2, no melting occurs in the uppermost $200 \mathrm{~m}$ of the water column because the sea-ice cover is thick (about $10 \mathrm{~m}$ ) and perennial (see Colleoni et al., 2014). Below this depth and until about $500 \mathrm{~m}$ depth, which goes beyond the depth of the grounding lines in our simulations (Table 3), it leads to basal melt rates larger than $0.4 \mathrm{~m} / \mathrm{yr}$ for both climate simulations when using Martin et al. (2011) parametrisation, and to basal melt rates lower than $0.1 \mathrm{~m} / \mathrm{yr}$ when using Holland et al. (2008). Given that the SMB over the Siberian Sea is less than $0.3 \mathrm{~m} / \mathrm{yr}$ on average, the use of Martin et al. (2011) parametrisation could inhibit the growth of the ice shelf. On the contrary, the rates obtained using Holland et al. (2008) are close to what was prescribed in our experiments (especially SHELF007 and SHELF008) and would probably leads to ice shelves of comparable dimensions to those described in the present study. However, the use of simulated vertical ocean temperature distribution does not reduce the overall uncertainty regarding how well the true temperature distribution is approximated. In fact, the simulated ocean vertical structure might be model-dependent due to differences in mixing and diffusion related parameters, as well as the type and length of the ocean model spin-up. As pointed out by O'Regan et al. (2008), a reconstruction of vertical temperature distribution in the Arctic Ocean is not available for the Late Pleistocene. Therefore, a proper evaluation of the simulated Arctic Ocean dynamics on past glaciations is currently not possible. Caution is moreover advised when applying parametrisations derived in a specific geographical setting (Holland et al., 2008; Martin et al., 2011, parametrisations are developed for present-day Antarctic modelling purposes) to different regions and/or different time periods.

\subsection{Steady-state versus transient: time of growth}

In order to shed light on the sensitivity of the ice cap and ice shelf geometries to model parameters, all ice sheet simulations presented here were run for 30000 years using constant climate forcing. The results show that equilibrium is reached after about 20,000 years when using K140T1 climate forcing (Fig. 6) and about 5000 years earlier when using K140T2 (Fig. 7). This discrepancy is explained by the fact that K140T2 is colder over Beringia than K140T1, which limits the melting of the ice cap during summer (Fig. 3) and therefore sustains the ice shelf growth with larger ice fluxes than when using K140T1. Furthermore, due to circulation changes induced by the lower Laurentide ice sheet, more precipitation is able to reach the Chukchi Sea where the ice shelf is growing. Therefore the growth and expansion rates of the ice shelf are much larger - and thus approach equilibrium faster - when using K140T2 climate forcing than when using K140T1. In the present work, we force all our simulations using these two glacial maximum climate forcing because we assumed that the Beringia ice cap and ice shelf grew under glacial climate conditions. Niessen et al. (2013) does not provide any precise timing for the growth of the ice cap over Beringia. Glacial conditions are generally dry, which is not favourable for the growth of ice bodies. Therefore, when performing equilibrium simulations, the length of the simulation compensates for the lack of precipitation and allow to built massive ice caps and ice sheets. As a consequence, our simulations might overestimate the volume and the extent of the ice shelf and the ice cap over Beringia. In nature, the climate evolves continuously and an ice sheet is never in equilibrium with the climate. The $\delta^{18} \mathrm{O}$ record from North GRIP suggests that prior the LGM, climate was warmer and wetter and gradually cooled toward glacial conditions (North GRIP members, 2004). Therefore, it is likely that in transient simulations, an ice cap and an ice shelf can grow at faster rates before the glacial maximum of a cycle that at the glacial maximum. Because pre-glacial climate conditions are also warmer, the summer melt is larger, which implies that higher temperatures might counterbalance the higher precipitation rates in a transient simulation, leading to a similar or smaller accumulated ice volume than in an equilibrium simulation.

\section{Conclusions}

Using previously simulated MIS 6 glacial maximum climate conditions, we forced an ice-sheet model in order to test the hypothesis that an ice cap and an ice shelf could have grown over Beringia during the MIS 6 glaciation ( $\approx 140$ kyrs BP) as suggested by the recent Arctic campaign data from Niessen et al. (2013). We investigate the impact of enhancement factors, calving, basal melting and surface mass balance parameters on the growth of the ice cap - ice shelf over Beringia. Our results show that:

- During MIS 6 glacial maximum climate conditions, an ice cap, whose volume ranges between $8 \mathrm{~m}$ SLE and $14 \mathrm{~m} \mathrm{SLE}$, develops over Beringia. At its seaward margin, it provides ice fluxes large enough to spread an ice shelf in the area of the East Siberian Sea of dimension comparable to that of the current Ross ice shelf in Antarctica.

- All parameters investigated influence the timing of ice shelf growth, and its final spatial configuration. Furthermore, the dimension of the ice cap and its geometry directly influence the geometry of the ice shelf. Calving cut-off threshold and standard deviation of the surface temperature are the two parameters that have the greatest influence on the growth of the ice shelf. When we set low values, the Arctic Ocean becomes fully ice covered.

- Merging of the Beringia ice cap and the Eurasian ice sheet affects the expansion of the ice shelf only if the ice cap fluxes are not large enough to compensate for the fluxes coming from the 
Eurasian ice sheet and sustain the growth of the ice shelf. This concerns all the simulations under K140T1 climate forcing exhibiting a small monodome ice cap over Beringia. In the simulations where the ice cap exhibits two major domes, the ice dome located over the easternmost part of Siberia sustains independently the expansion of the ice shelf off the East Siberia Sea.

\section{Acknowledgements}

This study has been partly funded by the SKB management Company. We gratefully acknowledge the financial support of Italian Ministry of Education. We acknowledge the two anonymous reviewers for the very constructive suggestions and to Catherine Ritz for providing the ice sheet model.

\section{References}

Alvarez-Solas, J., Montoya, M., Ritz, C., Ramstein, G., Charbit, S., Dumas, C. Nisancioglu, K., Dokken, T., Ganopolski, A., 2011. Heinrich event 1: an example of dynamical ice-sheet reaction to oceanic changes. Clim. Past 7, 1297-1306.

Amante, C., Eakins, B., 2009. ETOPO1 1 Arc-minute Global Relief Model: Procedures Data Sources and Analysis. US Department of Commerce, National Oceanic and Atmospheric Administration, National Environmental Satellite, Data, and Information Service, National Geophysical Data Center, Marine Geology and Geophysics Division.

Bamber, J., Griggs, J., Hurkmans, R., Dowdeswell, J., Gogineni, S., Howat, I., Mouginot, J., Paden, J., Palmer, S., Rignot, E., et al., 2013. A new bed elevation dataset for Greenland. Cryosphere 7, 499-510.

Basilyan, A., Nikol'skyi, P., Anisimov, M., 2008. Pleistocene glaciation of the New Siberian Islands - no more doubt. IPY News 12, 7-9.

Berger, A., Loutre, M., 1991. Insolation values for the climate of the last 10 millions years. Quat. Sci. Rev. 10, 297-317.

Brady, E., Otto-Bliesner, B., Kay, J., Rosenbloom, N., 2013. Sensitivity to glacial forcing in the CCSM4. J. Clim. 26, 1901-1925.

Brigham-Grette, J., 2013. Palaeoclimate: a fresh look at arctic ice sheets. Nat. Geosci. 6, 807-808.

Charbit, S., Ritz, C., Ramstein, G., 2002. Simulations of northern hemisphere icesheet retreat: sensitivity to physical mechanisms involved during the last deglaciation. Quat. Sci. Rev. 23, 245-263.

Charbit, S., Ritz, C., Philippon, G., Peyaud, V., Kageyama, M., 2007. Numerical reconstructions of the northern hemisphere ice sheets through the last glacialinterglacial cycle. Clim. Past 3, 15-37.

Colleoni, F., 2009. On the Late Saalian Glaciation (160-140 Ka): a Climate Modeling Study. Ph.D. thesis. Université Joseph-Fourier-Grenoble I; Stockholm University.

Colleoni, F., Krinner, G., Jakobsson, M., 2009a. Sensitivity of the Late Saalian (140 kyrs BP) and LGM (21 kyrs BP) Eurasian ice sheet surface mass balance to vegetation feedbacks. Geophs. Res. Lett. 36, L08704.

Colleoni, F., Krinner, G., Jakobsson, M., Peyaud, V., Ritz, C., 2009b. Influence of regional factors on the surface mass balance of the large Eurasian ice sheet during the peak Saalian (140 kyrs BP). Glob. Planet. Change 68, 132-148.

Colleoni, F., Krinner, G., Jakobsson, M., 2010a. The role of the Late Saalian Arctic iceshelf in the climate of the last glacial maximum of MIS 6 (140 kyrs BP). Quat. Sci. Rev. 29, 3590-3597.

Colleoni, F., Liakka, J., Krinner, G., Jakobsson, M., Masina, S., Peyaud, V., 2010b. The sensitivity of the Late Saalian (140 ka) and LGM (21 ka) Eurasian ice sheets to sea surface conditions. Clim. Dynam. 37, 531-553.

Colleoni, F., Wekerle, C., Masina, S., 2014. Long-term Safety of a Planned Geological Repository for Spent Nuclear Fuel in Forsmark - Estimate of Maximum Ice Sheet Thicknesses. Technical Report SKB TR-14-21. SKB.

Dove, D., Polyak, L., Coakley, B., 2014. Widespread, multi-source glacial erosion on the Chukchi margin, Arctic Ocean. Quat. Sci. Rev. 92, 112-122.

Durand, G., Gillet-Chaulet, F., Svensson, A., Gagliardini, O., Kipfstuhl, S. Meyssonnier, J., Parrenin, F., Duval, P., Dahl-Jensen, D., 2007. Change in ice rheology during climate variations-implications for ice flow modelling and dating of the epica dome c core. Clim. Clim. Past. 3, 155-167.

Dyke, A., Andrews, J., Clark, P., England, J., Miller, G., Shaw, J., Veillette, J., 2002. The laurentide and innuitian ice sheets during the last glacial maximum. Quat. Sci. Rev. 21.

Engels, J., Edwards, M., Polyak, L., Johnson, P., 2008. Sea floor evidence for ice shelf flow across the Alaska-Beaufort margin of the Arctic Ocean. Earth Surf. Process. 33, 1047-1063.

Gent, P.R., Danabasoglu, G., Donner, L.J., Holland, M.M., Hunke, E.C., Jayne, S.R., Lawrence, D.M., Neale, R.B., Rasch, P.J., Vertenstein, M., Worley, P.H., Yang, Z.L., Zhang, M., 2011. The community climate system model version 4. J. Clim. 24 4973-4991.

Grosswald, M., 1989. ?Submerged shorelines? on glaciated continental shelves: solving the puzzle? J. Coast. Res. 113-121.

Grosswald, M., Hughes, T., 1999. The case for an ice shelf in the Pleistocene Arctic
Ocean. Polar Geogr. 23, 23-54

Hinz, K., Delisle, G., Block, M., 1998. Seismic evidence for the depth extent of permafrost in shelf sediments of the Laptev Sea, Russian Arctic. In: Proceedings of the 7th International Conference on Permafrost, pp. 453-458.

Holland, P., Jenkins, A., Holland, D., 2008. The response of ice shelf basal melting to variations in ocean temperature. J. Clim. 21, 2558-2572.

Hourdin, F., Musat, I., Bony, S., Braconnot, P., Cordon, F., Dufresne, J., Fairhead, L., Filiberti, M., Friedlingstein, P., Grandpeix, J., Krinner, G., LeVan, P., Li, Z., Lott, F., 2006. The LMDZ4 general circulation model: climate performance and sensitivity to parametrized physics with emphasis on tropical convection. Clim. Dynam. 27, 783-813.

Hughes, B.A., Hughes, T.J., 1994. Transgressions: rethinking beringian glaciation. Palaeogeogr. Palaeocl 110, 275-294.

Hughes, T., Denton, G., Grosswald, M., 1977. Was there a late-Würm Arctic ice sheet. Nature 266.

Hutter, K., 1983. Theoretical Glaciology: Material Science of Ice and the Mechanics of Glaciers and Ice Sheets. Reidel Publishing Company, Dordrecht, The Netherlands.

Jakobsson, M., 1999. First high-resolution chirp sonar profiles from the central Arctic Ocean reveal erosion of Lomonosov Ridge sediments. Mar. Geol. 158, $111-123$.

Jakobsson, M., Løvlie, R., Arnold, E., Backman, J., Polyak, L., Knutsen, J.O., Musatov, E., 2001. Pleistocene stratigraphy and paleoenvironmental variation from lomonosov ridge sediments, central arctic ocean. Glob. Planet. Change 31, 1-22.

Jakobsson, M., Gardner, J., Vogt, P., Mayer, L., Armstrong, A., Backman, J., Brennan, R., Calder, B., Hall, J., Kraft, B., 2005. Multibeam bathymetric and sediment profiler evidence for ice grounding on the chukchi borderland, arctic ocean. Quat. Res. 63, 150-160.

Jakobsson, M., Polyak, L., Edwards, M., Kleman, J., Coakley, B., 2008. Glacial geomorphology of the central arctic ocean: the chukchi borderland and the lomonosov ridge. Earth Surf. Proc. Land 33, 526-545.

Jakobsson, M., Nilsson, J., O'Regan, M., Backman, J., Löwemark, L., Dowdeswell, J.A., Mayer, L., Polyak, L., Colleoni, F., Anderson, L., et al., 2010. An Arctic Ocean ice shelf during MIS 6 constrained by new geophysical and geological data. Quat. Sci. Rev. 29, 3505-3517.

Jakobsson, M., Andreassen, K., Bjarnadóttir, L.R., Dove, D., Dowdeswell, J.A., England, J.H., Funder, S., Hogan, K., Ingólfsson, Ó., Jennings, A., et al., 2014. Arctic Ocean glacial history. Quat. Sci. Rev. 92, 40-67.

Kageyama, M., Braconnot, P., Bopp, L., Mariotti, V., Roy, T., Woillez, M.N., Caubel, A., Foujols, M.A., Guilyardi, E., Khodri, M., et al., 2013. Mid-Holocene and last glacial maximum climate simulations with the IPSL model: part II: model-data comparisons. Clim. Dynam. 40, 2469-2495.

Kleiber, H.P., Niessen, F., 1999. Late pleistocene paleoriver channels on the laptev sea shelf-implications from sub-bottom profiling. Land Ocean Syst. Sib. Arct. $657-665$.

Krinner, G., Boucher, O., Balanski, Y., 2006. Ice-free glacial northern Asia due to dust deposition on snow. Clim. Dynam. 27, 773-777.

Lambeck, K., Purcell, A., Funder, S., Kjaer, K., Larsen, E., ans Möller, P., 2006. Constraints on the Late Saalian to early Middle Weichselian ice sheet of Eurasia from field data and rebound modelling. Boreas 35, 539-575.

Laske, G., Masters, G., 1997. A global digital map of sediment thickness. EOS Trans. AGU 78.

Lemeur, E., Huybrechts, P., 1996. A comparison of different ways of dealing with isostasy: examples from modeling the Antarctic ice sheet during the last glacial cycle. Ann. Glaciol. 23, 309-317.

Ma, Y., Gagliardini, O., Ritz, C., Gillet-Chaulet, F., Durand, G., Montagnat, M., 2010. Enhancement factors for grounded ice and ice shelves inferred from an anisotropic ice-flow model. J. Glaciol. 56, 805-812.

MacAyeal, D., 1989. Large-scale ice flow over a viscous basal sediment: theory and application to ice stream B, Antarctica. J. Geophys. Res. 94, 4071-4087.

Marsiat, I., 1994. Simulation of the Northern Hemisphere continental ice sheets over the last glacial-interglacial cycle: experiments with a latitude-longitude vertically integrated ice sheet model coupled to a zonally averaged climate model. Paleoclimates 1, 59-98.

Martin, M., Winkelmann, R., Haseloff, M., Albrecht, T., Bueler, E., Khroulev, C. Levermann, A., 2011. The potsdam parallel ice sheet model (PISM-PIK)-Part 2: dynamic equilibrium simulation of the antarctic ice sheet. Cryosphere 5, $727-740$.

Mercer, J., 1970. A former ice sheet in the Arctic Ocean? Palaeogeogr. Palaeocl. 8, $19-27$.

Möller, P., Alexanderson, H., Funder, S., Hjort, C., 2015. The Taimyr Peninsula and the Severnaya Zemlya archipelago, Arctic Russia: a synthesis of glacial history and palaeo-environmental change during the Last Glacial cycle (MIS 5e-2). Quat. Sci. Rev. 107, 149-181.

Niessen, F., Hong, J.K., Hegewald, A., Matthiessen, J., Stein, R., Kim, H., Kim, S., Jensen, L., Jokat, W. Nam, S., et al., 2013. Repeated Pleistocene glaciation of the East Siberian continental margin. Nat. Geosci. 6, 842-846.

North GRIP members, 2004. High-resolution record of northern hemisphere climate extending into the last interglacial period. Nature 431, 147-151.

Nürnberg, D., Dethleff, D., Tiedemann, R., Kaiser, A., Gorbarenko, S., 2011. Okhotsk Sea ice coverage and Kamchatka glaciation over the last 350ka?Evidence from ice-rafted debris and planktonic $\delta^{18}$ O. Palaeogeogr. Palaeocl 310, 191-205.

O'Regan, M., King, J., Backman, J., Jakobsson, M., Plike, H., Moran, K., Heil, C., Sakamoto, T., Cronin, T., Jordan, R., 2008. Constraints on the pleistocene chronology of sediments from the lomonosov ridge. Paleoceanography 23, PA1S19. 
Peltier, W., 2004. Global glacial isostasy and the surface of the ice-age earth: the ice5g (vm2) model and grace. Annu. Rev. Earth Pla. Sci. 32, 111-149.

Petit, J., Jouzel, J., Raynaud, D., Barkov, N., Barnola, J., Basile, I., Bender, M., Chapellaz, J., Davis, J., Delaygue, G., Delmotte, M., Kotlyakov, V., Legrand, M., Lipenkov, V., Lorius, C., Ppin, L., Ritz, C., Saltzman, E., Stievenard, M., 1999. Climate and atmospheric history of the past 420,000 years from the Vostok ice core, Antarctica. Nature 399, 429-436.

Peyaud, V., 2006. Role of the Ice Sheet Dynamics in Major Climate Changes. Ph.D. thesis. Laboratoire de Glaciologie et de Géophysique de l'Environnement, Université Grenoble I.

Peyaud, V., Ritz, C., Krinner, G., 2007. Modeling the early weichselian Eurasian ice sheets: role of ice shelves and influence of ice-dammed lakes. Clim. Past 3, 375-386.

Polyak, L., Edward, M., Coakley, B., Jakobsson, M., 2001. Ice shelves in the Pleistocene Arctic Ocean inferred from glaciogenic deep-sea bedforms. Nature 410, 453-457.

Polyak, L., Bischof, D.D.J., Jakobsson, M., 2007. Stratigraphic constraints on late Pleistocene glacial erosion and deglaciation of the Chukchi margin, Arctic Ocean. Quat. Res. 67, 234-245.

Rabineau, M., Berne, S., Olivet, J., Aslanian, D., Guillocheau, F., Joseph, P., 2006. Paleo sea levels reconsidered from direct observation of paleoshore-line position during glacial maxima (for the last 500,000 yr). Earth Planet. Sci. Lett. 252, 119-137.

Reeh, N., 1991. Parameterization of melt rate and surface temperature on the greenland lce sheet. Polarforschung 5913, 113-128.

Ritz, C., Rommalaere, V., Dumas, C., 2001. Modeling the evolution of antarctic ice sheet over the last 420,000 years: implications for altitude changes in the vostok region. J. Geophys. Res. 106, 31943-31964.

Romanovskii, N., Hubberten, H.W., 2001. Results of permafrost modelling of the lowlands and shelf of the Laptev Sea region, Russia. Permafr. Perigla 12 191-202.
Rommelaere, V., Ritz, C., 1996. A thermomechanical model of ice-shelf flow. Ann. Glaciol. 23, 13-20.

Schirrmeister, L., Kunitsky, V., Grosse, G., Wetterich, S., Meyer, H., Schwamborn, G. Babiy, O., Derevyagin, A., Siegert, C., 2011. Sedimentary characteristics and origin of the Late Pleistocene Ice Complex on north-east Siberian Arctic coastal lowlands and islands-a review. Quatern. Int. 241, 3-25.

Shapiro, N., Ritzwoller, M., 2004. Inferring surface heat flux distributions guided by a global seismic model: particular ap- plication to Antarctica. Earth Planet. Sci. Lett. 223, 213-214.

Spahni, R., Chappellaz, J., Stocker, T., Loulergue, L., Hausammann, G., Kawamura, K., Flückiger, J., Schwander, J., Raynaud, D., Masson-Delmotte, V., et al., 2005. Atmospheric methane and nitrous oxide of the late Pleistocene from Antarctic ice cores. Science 310, 1317-1321.

Stauch, G., Lehmkuhl, F., 2010. Quaternary glaciations in the verkhoyansk mountains, northeast siberia. Quat. Res. 74, 145-155.

Stein, R., Boucsein, B., Fahl, K., de Oteyza, T.G., Knies, J., Niessen, F. 2001. Accumulation of particulate organic carbon at the Eurasian continental margin during late Quaternary times: controlling mechanisms and paleoenvironmental significance. Glob. Planet. Change 31, 87-104.

Svendsen, J. Alexanderson, H., Astakhov, V. Demidov, I., Julian, A., Funder, S, Gataulling, V., Henriksen, M., Hjort, J., Houmark-Nielsen, M., Hubberten, H., Ingulfsson, O., Jakobsson, M., Kjer, K., Larsen, E., Lokrantz, H., Lunkka, J., Lys, A., Mangerud, J., Matiouchkov, A., Murray, A., Muller, P., Niessen, F., Nikolskaya, O., Polyak, L., Saarnisto, M., Siegert, C., Siegert, M., Spielhagen, R., Stein, R., 2004. Late Quaternary ice sheet history of Northern Eurasia. Quat. Sci. Rev. 23 1229-1271.

Waelbroeck, C., Labeyrie, L., Michel, E., Duplessy, J., McManus, J., Lambeck, K, Balbon, E., Labracherie, M., 2002. Sea-level and deep water temperature changes derived from benthic foraminifera isotopic records. Quat. Sci. Rev. 21 295-305. 